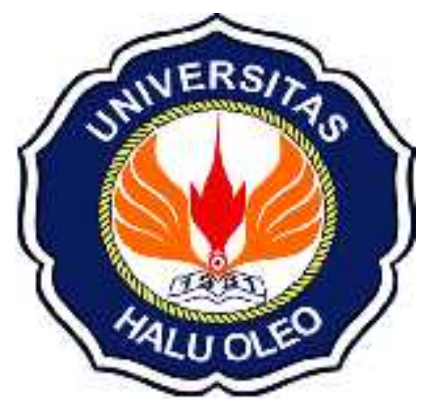

\title{
ANALISIS PENGENDALIAN MUTU PENGOLAHAN IKAN BEBY TUNA BEKU PADA PT ABADI MAKMUR OCEAN KENDARI
}

Tahun ke 1 (satu) dari rencana 1 (satu) tahun

Dibiayai Oleh:

Daftar Isian Pelaksana Anggaran dana DIPA - BLU Universitas Halu Oleo Nomor: SP-DIPA-042.01.2.400909/2017, Tanggal 7 Desember 2017

\section{TIM PENELITI}

RISKI AMALIA MADI, SE., M,Si. (Ketua) NIDN : 0010038006

NENENG LAGATARI, SE., M.Si. (Anggota) NIDN : 0018017908

\section{UNIVERSITAS HALU OLEO}

KENDARI 
Judul Penelitian

Kode/Nama Rumpun Ilmu

Peneliti
a. Nama Lengkap
b. NIDN
c. Jabatan Fungsional
d. Program Studi
e. Nomor HP
f. Alamat Surel
Riski Amalia Madi, SE, MSi
0010038006
Tenaga Pendidik
Manajemen
081341507556
riski amalia98@a yahoo com

Anggota Peneliti
a. Nama Lengkap
b. NIDN
c. Perguruan Tinggi Biaya Penelitian
Neneng Lagatari, SE, M.Si.
0018017908
Universitas Haluoleo
Rp 5.000 .000

: Analisis Pengendalian Mutu Pada Pengolahan Ikan Baby Tuna Beku Pada PT Abadi Makmur Ocean Kendari

: 571/Manajemen

Kendari, 30 November 2017
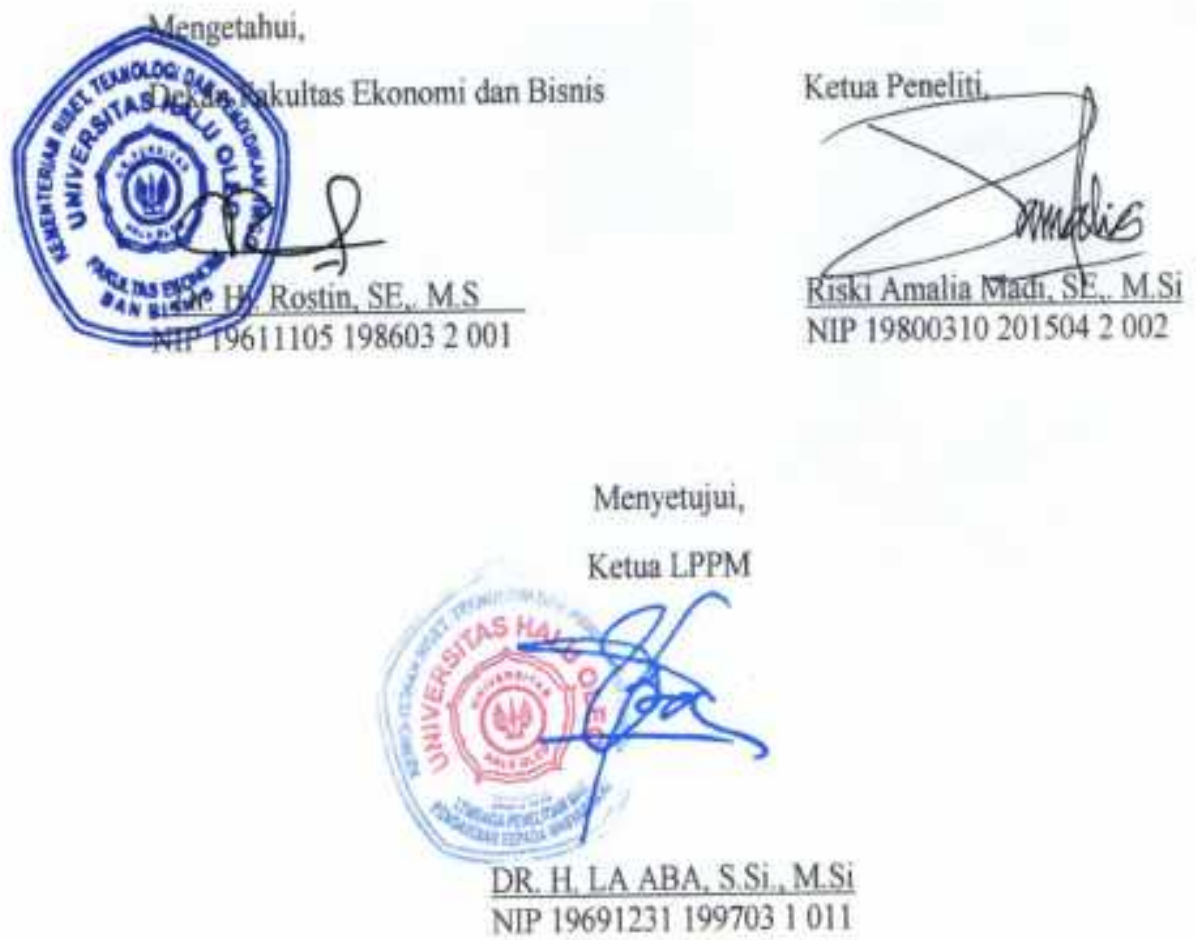


\section{RINGKASAN}

Pengendalian kualitas dibutuhkan untuk mengurangi atau meminimalisir tingkat kerusakan yang mungkin terjadi dalam proses pembuatan atau pengolahan produk sehingga tidak menimbulkan tambahan biaya yaitu biaya pengawasan kualitas dan tingkat kerusakan produk yang dihasilkan sangat sedikit. Usaha pengendalian kualitas merupakan usaha preventif (penjagaan) perusahaan yang dilaksanakan sebelum kesalahan kualitas produk terjadi.

Tujuan dalam penelitian ini adalah untuk mengetahui pelaksanaan pengendalian mutu pada pengolahan Ikan Beby tuna beku apakah sudah berada pada batas kendali dengan menganalisis sistem pengendalian mutu untuk meminimumkan kerusakan pengolahan Ikan Beby tuna beku dengan pendekatan statistical quality control (SQC) pada PT. Abadi Makmur Ocean (AMO).

Pelaksanaan Pengendalian Mutu Pengolahan Ikan Beby Tuna pada PT. PT Abadi Makmur Ocean (AMO) sudah memiliki standar operasional kerja sesuai dengan ketentuan $\mathrm{K} 3$ dengan standar mutu hasil yang tinggi karena untuk di ekspor. Hasil analisis Statistical Quality Control (SQC) dengan metode diagram kendali P ( $P$-charts) menunjukan besarnya nilai garis sentral yaitu 0,40471 atau $40,47 \%$, nilai batas kendali atas (UCL) yaitu 0,4531 atau $45,31 \%$ yang berarti jika produk yang cacat/rusak mencapai atau berada di atas batas kendali atas (UCL) maka proses beby tuna yang dilakukan pada perusahaan dianggap tidak efektif, sebaliknya produk cacat/rusak berada pada batas kendali bawah (LCL) menunjukan nilai sebesar 0,3563 atau 35,63\% berarti proses produksi beby tuna menunjukan cukup efektif. Hal ini terbukti dari hasil pemeriksaan sampel ikan beby tuna komoditas ekspor pada bulan Oktober-November 2017 dengan 21 hari kerja, hanya satu hari yaitu hari ke 15 jumlah produk yang mengalami kerusakan karena berada diluar batas pengawasan kualitas atau terjadi penyimpangan kualitas serta pengamatan kondisi sanitasi higiene dan lingkungan pada PT Abadi Makmur Ocean (AMO) secara keseluruhan kondisinya sudah sesuai dengan standar pengendalian mutu dan keamanan hasil perikanan di sentra penyendia pangan sehat yang di terapkan oleh Badan Karantina Ikan, Pengendalian Mutu Dan Keamanan Hasil Perikanan Selaku Otoritas Kompeten.

Kata Kunci : Pengawasan Mutu, Statistical Quality Control, Sanitasi Higiene dan Lingkungan 


\section{PRAKATA}

Puji syukur kami panjatkan kehadirat Allah SWT yang telah memberikan rahmat serta karunia-Nya kepada kami sehingga kami berhasil menyelesaikan laporan akhir ini. Kami menyadari, dalam penyusun laporan ini masih jauh dari kesempurnaan. Oleh karenanya, kami mohon saran dan kritik yang sifatnya membangun dari rekan-rekan dan semua pihak yang terkait.

Terimakasih kepada semua pihak yang telah membantu terlaksananya penelitian dan penyusuan laporan ini sehingga bisa terselesaikan. Akhirnya, kami berharap semoga laporan kemajuan penelitian dosen pemula tahun 2017 membawa banyak manfaat bagi kita semua.

Kendari, 30 November 2017

Tim Peneliti Dosen Pemula 


\section{DAFTAR ISI}

HALAMAN SAMPUL........................................................................ i

HALAMAN PENGESAHAN............................................................. ii

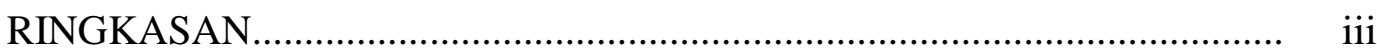

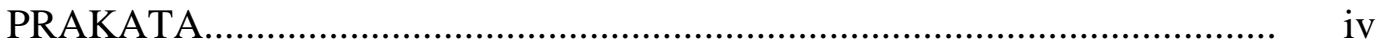

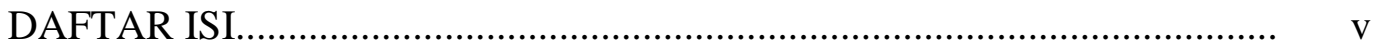

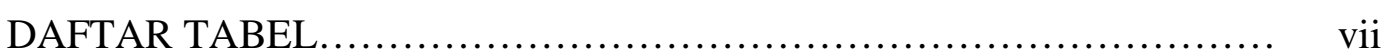

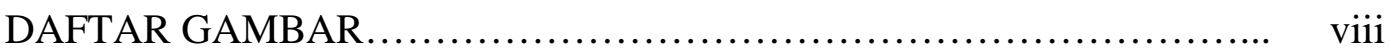

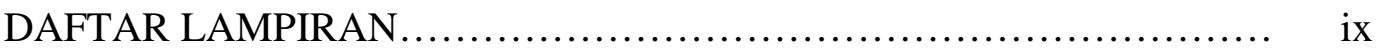

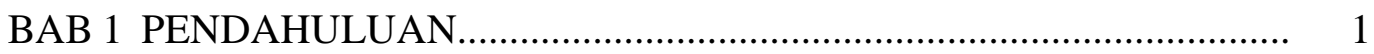

1.1 Latar Belakang.......................................................................... 1

1.2 Rumusan Masalah....................................................................... 4

BAB 2 TINJAUAN PUSTAKA.......................................................... 5

2.1 Definisi Kualitas/Mutu ............................................................. 5

2.2 Pengendalian Kualitas............................................................. 6

2.3 Tahapan Pengendalian Kualitas..................................................... $\quad 7$

2.4 Pengendalian Kualitas Statistik....................................................... 8

2.5 Proses Kemunduran Mutu Ikan .................................................... 9

2.6 Penelitian Serupa yang Pernah Dilakukan Sebelumnya................... 9

BAB 3 TUJUAN DAN MANFAAT PENELITIAN ................................... 11

3.1 Tujuan.............................................. 11

3.2 Manfaat................................................... 11

BAB 4 METODE PENELITIAN ................................... 12

4.1 Lokasi dan Waktu Penelitian.............................................................. 12

4.2 Data, Responden, Analisis Data..................................................... 12

BAB 5 HASIL DAN PEMBAHASAN................................................... 14

5.1 Sejarah Perusahaan........................................ 14

5.2 Struktur Organisasi............................................ 17

5.3 Aspek Kemitraan Perusahaan............................... 18

5.4 Pelaksanaan Pengendalian Mutu Pengolahan Ikan Beby Tuna Beku 19 
5.5 Sistem Pengendalian Mutu dengan Pendekatan Statistical Quality Control

5.6 Pengamatan Kondisi Sanitasi Higiene dan Lingkungan Pada PT AMO

BAB 6 KESIMPULAN DAN SARAN 27

6.1 Kesimpulan 27

6.2 Saran.... 27

DAFTAR PUSTAKA 28

LAMPIRAN 29 


\section{DAFTAR TABEL}

Tabel 2.1 Penelitian Terdahulu.................................................................... $\quad 10$

Tabel 5.1 Hasil evaluasi rata-rata Beby Tuna pada bulan Oktober $2017 \quad 22$ PT AMO.

Tabel 5.2 Kondisi Sanitasi Higiene dan Lingkungan pada PT Abadi Makmur 23 Ocean (AMO) 


\section{DAFTAR GAMBAR}

Gambar 5.1 Kantor PT Abadi Makmur Ocean.............................................. 16

Gambar 5.2 Struktur Organisasi..................................... 17

Gambar 5.3 Aktivitas Karyawan bagian Penyortiran dan Penyusunan Ikan 20 Beby Tuna PT AMO....

Gambar5.4 Diagram Kendali $\mathrm{P}$ (P-charts) utuk jenis Beby 23 Tuna. 


\section{DAFTAR LAMPIRAN}

Lampiran 1 Susunan Organisasi Tim Pengeusul dan Pembagian Tugas....... 31

Lampiran 2 Surat Pernyataan Ketua Pelaksana............................ 32

Lampiran 3 Biodata Ketua dan Anggota Tim Pengusul.................... 33

Lampiran 4 Draft Artikel Publikasi Penelitian.................................. 36 


\section{BAB 1}

\section{PENDAHULUAN}

\subsection{Latar Belakang}

Indonesia sebagai negara kepulauan terbesar d

i dunia memiliki laut yang luasnya sekitar 5,8 juta $\mathrm{km}^{2}$ dan menurut World Resources Institute tahun 1998 memilki garis pantai sepanjang $91.181 \mathrm{~km}$ yang di dalamnya terkandung sumber daya perikanan dan kelautan yang mempunyai potensi besar untuk dijadikan tumpuan pembangunan ekonomi berbasis sumber daya alam (www.prospekperikananindonesiasma4.weebly.com)

Besarnya potensi ini terlihat dari tersedianya luas areal budidaya perikanan yang terus meningkat dalam enam tahun terakhir (2011-2016). Tahun 2011 luas area budidaya ikan mencapai 1,19 juta hektar dan ditahun 2016 telah mencapai 1,44 juta hektar. Menurut survey dalam 6 tahun terakhir kondisi perikanan dalam negeri semakin membaik, hal ini terlihat dari semakin meningkatnya produksi, baik produksi perikanan tangkap maupun budidaya dengan rata rata pertumbuhan mencapai 20\% per tahun. Tahun 2011 perkembangan produksi perikanan budidaya mencapai 6,47 juta ton ditahun 2016 angkanya telah mencapai 19,75 juta ton, sedangkan produksi perikanan tangkap ditahun 2011 mencapai 5,71 juta ton dan tahun 2016 angkanya telah mencapai 7,97 juta ton. Hingga akhir 2016 nilai produksi perikanan Indonesia mencapai Rp. 139,2 triliun. (survey PT CDMI consulting,2017)

Dua tahun lalu 2014 dan 2015 industri pengolahan ikan di Asia Tenggara masih dikuasai oleh Thailand dan Filipina, sedangkan Indonesia sebagai pemilik lautan terluas dan garis pantai terpanjang menduduki posisi ketiga. Namun ditahun 2016 kondisinya sudah berubah, kekuatan industri perikanan di Asia Tenggara telah dikendalikan Indonesia. Selama ini ikan-ikan yang diolah oleh Thailand dan Filipina untuk kemudian mereka ekspor sebenarnya banyak yang berasal dari perairan Indonesia. Dengan kebijakan moratorium perizinan kapal eks asing, kini semakin sulit menangkap ikan diperairan Indonesia ditambah dengan kebijakan larangan bongkar muat ikan di tengah laut (transhipment) menambah terpuruk 
industri perikanan Thailand dan Filipina, sehingga akhirnya mereka mengajukan permohonan membuka pabrik pengolahan ikan di Indonesia.

Disamping Filiphina dan Thailand. China, Peru,USA dan negara kelautan lainnya merupakan pesaing Indonesia sebagai produsen perikanan dunia. Persaingan harga dan kualitas merupakan salah satu tantangan yang dihadapi oleh perusahaan pengolahan perikanan di Indonesia dari tingkat regional maupun global baik untuk bahan baku/ikan mentah atau produk dengan nilai tambah (Saut,2014). Dalam era persaingan global dibutuhkan taktik dan strategi perusahaan secara menyeluruh agar dapat bersaing dengan perusahaan lain. Perusahaan yang memiliki produk yang berkualitas kemungkinan akan berhasil memenangkan persaingan karena dapat memuaskan kebutuhan dan keinginan konsumen. Perhatian penuh terhadap kualitas akan memberikan dampak positif kepada bisnis melaui dua cara, yaitu dampak terhadap biaya produksi dan dampak terhadap pendapatan (Gaspersz,2005).

Dampak terhadap biaya produksi terjadi melalui proses pembuatan produk yang memiliki derajat konformansi yang tinggi terhadap standar-standar sehingga bebas dari tingkat kerusakan yang mungkin terjadi. Pengendalian kualitas dibutuhkan untuk mengurangi atau meminimalisir tingkat kerusakan yang mungkin terjadi dalam proses pembuatan atau pengolahan produk sehingga tidak menimbulkan tambahan biaya yaitu biaya pengawasan kualitas dan tingkat kerusakan produk yang dihasilkan sangat sedikit. Usaha pengendalian kualitas merupakan usaha preventif (penjagaan) perusahaan yang dilaksanakan sebelum kesalahan kualitas produk terjadi.

Pelabuhan Perikanan Samudera (PPS) Kendari sebagai pusat industri perikanan terpadu di Kawasan Timur Indonesia kini menghimpun sedikitnya 27 industri pengolahan ikan dan industri penunjang lainnya. Dari 27 perusahaan yang tergabung dalam kawasan PPS terpadu di Kecamatan Abeli itu, sebanyak 12 perusahaan industri pengolahan ikan dan 15 perusahaan industri penunjang. Dari 12 perusahaan industri pengolahan ikan salah satu diantaranya adalah $\quad$ PT. Abadi Makmur Ocean (AMO) bergerak pada usaha penampungan dan pengolahan. (http://www.antarasultra.com/,2016). 
PT. AMO mampu memproduksi total 300 ton/bulan pada saat musim puncak penangkapan ikan, sementara pada saat musim penangkapan normal total produksi siap jual yang mampu dihasilkan oleh perusahaan sekitar 100 ton/bulan dan pada masa paceklik seringkali perusahaan tidak mendapatkan bahan baku sehingga tidak beroperasi. Jenis ikan yang menjadi bahan baku PT. AMO berasal dari jenis Cakalang, Beby Tuna, Layang dan Deho dengan beragam ukuran. Jenis-jenis ikan ini diperoleh dair para nelayan tangkap yang beroperasi disekitar laut pesisir Kondari-Wawoni'i serta dari luar wilayah hingga Laut Sulawesi, laut Banda, Laut Maluku, dan Laut Arafuru.

PT. AMO memiliki standar operasional kerja sesuai dengan ketentuan K3 dengan standar mutu hasil yang tinggi karena untuk di ekspor. Selanjutnya waktu kerja karyawan juga telah terjadwal bagi pekerja tetap dengan ada insentif untuk lembur dan tip perusahaan. PT. AMO mempekerjakan tenaga kerja tetap sebanyak 40 karyawan termasuk staf dan sekretaris dan lebih dari 50 orang tenaga kerja lepas yang hampir secara keseluruhan merupakan tenaga kerja lokal dengan dominasi tingkat pendidikan rendah (SMA) namun memiliki pengalaman dan keterampilan yang tinggi di bidang pengolahan ikan.

Kegiatan produksi yang dilakukan oleh PT. AMO diperuntukan untuk keperluan konsumsi domestik dan ekspor. PT AMO dalam aktivitas produksinya melakukan pengendalian terhadap kualitas ikan yang dimulai sejak penangkapan, penanganan ikan Beby tuna di atas kapal oleh nelayan, penanganan ikan Beby tuna di pelabuhan /dermaga (Penerimaan di TP,Pencucian I, Pemotongan sirip,Sortasi Mutu, Pencucian II, Penimbangan, Pengusapan, Pengepakan dan Pelabelan) dan hingga pengiriman ke konsumen akhir.

Sebelum ikan Beby tuna di ekspor terlebih dahulu dilakukan pemeriksaan dari Bau, Warna, Kekenyalan, dan Rasa di tempat pendaratan tuna, kemudian setelah di periksa ikan diproses di unit pengolahan ikan. Proses ikan Beby tuna dilakukan dibawah pengawasan oleh quality control dari awal ikan masuk dan siap diekspor, tetapi fenomena empiris menunjukan bahwa ada permasalahan yang biasa terjadi adalah adanya komplain dari pelanggan terkait mutu ikan Beby tuna segar yang dikirim. Daging ikan Beby tuna setelah di terima di negara tujuan ditemukan adanya 
perubahan seperti warna yang sudah tidak merah, rasa yang berubah, dan daging ikan yang sudah tidak elastis atau kenyal lagi.

\subsection{Rumusan Masalah}

Berdasarkan pada uraian di atas maka dapat diketahui bahwa masalah pengendalian terhadap kualitas produk yang dihasilkan oleh sebuah perusahaan merupakan suatu hal yang penting dan membutuhkan kajian yang lebih mendalam dalam bentuk penelitian tentang "Penerapan Statistical Quality Control (SQC) Pada Pengolahan Komoditi Ekspor Ikan Beby Tuna. Manajemen Pengendalian Mutu Produksi pengolahan komoditi ekspor ikan Beby tuna yang nantinya diharapkan dapat memberikan kontribusi untuk meningkatkan kualitas produksi ikan Beby tuna dan memperluas pangsa pasar. 


\section{BAB 2}

\section{TINJAUAN PUSTAKA}

\subsection{Definisi Kualitas/Mutu}

Pengertian atau definisi kualitas mempunyai cakupan yang sangat luas,relatif, berbeda-beda dan berubah-ubah, sehingga definisi dari kualitas memiliki banyak kriteria dan sangat bergantung pada konteksnya terutama jika dilihat dari sisi penilaian akhir konsumen dan definisi yang diberikan oleh berbagai ahli serta dari sudut pandang produsen sebagai pihak yang menciptakan kualitas. Konsumen dan produsen itu berbeda dan akan merasakan kualitas secara berbeda pula sesuai dengan standar kualitas yang dimiliki masing-masing. Begitu pula para ahli dalam memberikan definisi dari kualitas juga akan berbeda satu sama lain karena mereka membentuknya dalam dimensi yang berbeda (Al Fakhri,2010).

Ada beberapa definisi mutu yang masing-masing memberikan definisi yang berbeda, ditinjau dari dasar pendefenisiannya. Adapun definisi mutu yang cukup populer ada lima jenis yaitu:

A. Menurut lembaga Amerika untuk pengawasan mutu (American Society for Quality Control) yang biasa disingkat dengan ASQC, mutu adalah karakteristik produk dan keistimewaan (feature) yang memenuhi kepuasan pelanggan.

B. Meurut Webster dalam kamusnya, mutu adalah tingkat atau derajat kehebatan suatu benda.

C. Berdasarkan penggunaan, mutu adalah apa yang diikatkan konsumen.

D. Berdasarkan manufaktur, mutu adalah derajat kecocokan produk dengan spesifikasi desain.

E. Berdasarkan produk, mutu adalah tingkat karakteristik produk yang dapat diukur.

Feingenbaum dalam wiratama (2011), menyatakan mutu adalah kepuasan pelanggan sepenuhnya (full costumer service satisfaction). Suatu produk bermutu apabila dapat memberi kepuasaan sepenuhnya kepada konsumen. Mutu dapat dijelaskan hanya pada tahap suplier, produsen, pengguna atau pelanggan, keputusan manajemen dan pendapat dari konsumen mempengaruhi dari mutu itu sendiri. Total Quality Control atau pengendalian mutu terpadu menurut Feingenbaum, menyatakan pengendalian harus dimulai dari perancangan produk dan berakhir hanya jika produk 
telah sampai ke tangan pelanggan yang puas. Prinsip utamanya adalah mutu merupakan pekerjaan setiap orang. Kendali mutu terpadu adalah suatu sistem yang efektif untuk memadukan pengembangan mutu berbagai kelompok dalam sebuah organisasi agar pemasaran, kerekayasaan, produksi dan jasa dapat berada pada tingkatan yang paling ekonomis agar pelanggan mendapat kepuasan penuh. Ia menyatakan bahwa kegiatan mutu dapat dikelompokkan ke dalam tiga kategori, yaitu:

1) Pengendalian rancangan baru, yakni menyertakan pembentukan dan keterandalan yang diperlukan untuk memenuhi kepuasan pelanggan yang di maksudkan, termasuk penghapusan atau pencarian tempat sumber-sumber gangguan mutu yang mungkin sebelum dimulai produksi formal.

2) Pengendalian bahan baku yang baru datang, yakni menyertakan penerimaan penyimpanan pada tingkatan mutu yang paling ekonomis, hanya suku cadang yang mutunya memenuhi persyaratan spesifikasi, dengan penekanan tanggung jawab pada penjual praktis sepenuhnya.

3) Pengendalian produk yakni kendali atas produk-produk pada sumber produksinya hingga ke pelayanan lapangan sehingga penyimpangan-penyimpangan spesifikasi mutu dapat dikoreksi sebelum produk-produk yang cacat atau tidak sesuai dibuat dan pelayanan yang tepat dapat dipertahankan di lapangan untuk menjamin ketersediaan mutu pembeli yang dimaksudkan sepenuhnya.

\subsection{Pengendalian Kualitas}

Dengan semakin banyaknya perusahaan yang berkembang di Indonesia dewasa ini, maka bagi manajemen, kualitas produk menjadi lebih penting dari sebelumnya. Persaingan yang sangat ketat menjadikan pengusaha semakin menyadari pentingnya kualitas produk agar dapat bersaing dan mendapat pangsa pasar yang lebih besar. Perusahaan membutuhkan suatu cara yang dapat mewujudkan terciptanya kualitas yang baik pada produk yang dihasilkannya serta menjaga konsistensinya agar tetap sesuai dengan tuntutan pasar yaitu dengan menerapkan sistem pengendalian kualitas (quality control) atas aktivitas proses yang dijalani. Dalam menjalankan aktivitas, pengendalian kualitas merupakan salah satu teknik yang perlu dilakukan mulai dari sebelum proses produksi berjalan, pada saat proses produksi, hingga proses produksi berakhir dengan menghasilkan produk akhir. Pengendalian kualitas dilakukan agar dapat menghasilkan produk berupa barang 
atau jasa yang sesuai dengan standar yang diinginkan dan direncanakan, serta memperbaiki kualitas produk yang belum sesuai dengan standar yang telah ditetapkan dan sedapat mungkin mempertahankan kualitas yang telah sesuai. Menurut Vincent Gasperz (2005:480), pengendalian kualitas adalah: "Quality control is the operational techniques and activities used to fulfill requirements for quality".

Berdasarkan pengertian di atas, maka dapat ditarik kesimpulan bahwa pengendalian kualitas adalah suatu teknik dan aktivitas/ tindakan yang terencana yang dilakukan untuk mencapai, mempertahankan dan meingkatkan kualitas suatu produk dan jasa agar sesuai dengan standar yang telah ditetapkan dan dapat memenuhi kepuasan konsumen.

\subsection{Tahapan Pengendalian Kualitas}

Untuk memperoleh hasil pengendalian kualitas yang efektif, maka pengendalian terhadap kualitas suatu produk dapat dilaksanakan dengan menggunakan teknik-teknik pengendalian kualitas, karena tidak semua hasil produksi sesuai dengan standar yang telah ditetapkan. Menurut Suyadi Prawirosentono dalam Fakri (2010), terdapat beberapa standar kualitas yang bisa ditentukan oleh perusahaan dalam upaya menjaga output barang hasil produksi diantaranya:

1. Standar kualitas bahan baku yang akan digunakan.

2. Standar kualitas proses produksi (mesin dan tenaga kerja yang melaksanakannya).

3. Standar kualitas barang setengah jadi.

4. Standar kualitas barang jadi.

5. Standar administrasi, pengepakan dan pengiriman produk akhir tersebut sampai ke tangan konsumen.

Dikarenakan kegiatan pengendalian kualitas sangatlah luas, untuk itu semua pengaruh terhadap kualitas harus dimasukkan dan diperhatikan. Secara umum menurut Suyadi Prawirosentono (2007;74), pengendalian atau pengawasan akan kualitas di suatu perusahaan manufaktur dilakukan secara bertahap meliputi hal-hal sebagai berikut: 
1. Pemeriksaan dan pengawasan kualitas bahan mentah (bahan baku, bahan baku penolong dan sebagainya), kualitas bahan dalam proses dan kualitas produk jadi. Demikian pula standar jumlah dan komposisinya.

2. Pemeriksaan atas produk sebagai hasil proses pembuatan. Hal ini berlaku untuk barang setengah jadi maupun barang jadi. Pemeriksaan yang dilakukan tersebut memberi gambaran apakah proses produksi berjalan seperti yang telah ditetapkan atau tidak.

3. Pemeriksaan cara pengepakan dan pengiriman barang ke konsumen. Melakukan analisis fakta untuk mengetahui penyimpangan yang mungkin terjadi.

4. Mesin, tenaga kerja dan fasilitas lainnya yang dipakai dalam proses produksi harus juga diawasi sesuai dengan standar kebutuhan. Apabila terjadi penyimpangan, harus segera dilakukan koreksi agar produk yang dihasilkan memenuhi standar yang direncanakan.

\subsection{Pengendalian Kualitas Statistik}

Pengendalian kualitas statistik dilakukan dengan menggunakan alat bantu statistik yang terdapat pada SPC (Statistical Process Control) dan SQC (Statistical Quality Control) merupakan teknik penyelesaian masalah yang digunakan untuk memonitor, mengendalikan, menganalisis, mengelola dan memperbaiki produk dan proses menggunakan metode-metode statistik. Pengendalian kualitas statistik (Statistical Quality Control/ SQC) sering disebut sebagai pengendalian proses statistik (Statistical Process Control/ SPC). Dr. W. Edwards Deming adalah salah seorang yang memperkenalkan teknik penyelesaian masalah dan pengendalian dengan metode statistik tersebut (yang dikembangkan pertama kali oleh Shewhart) agar perusahaan dapat membedakan penyebab sistematis dan penyebab khusus dalam menangani kualitas. Menurut Heizer dan Render (2006:268) yang dimaksud dengan Statistical Process Control (SPC) adalah "A process used to monitor standars, making measurements and taking corrective action as a product or service is being produced." (Sebuah proses yang digunakan untuk mengawasi standar, membuat pengukuran dan mengambil tindakan perbaikan selagi sebuah produk atau jasa sedang diproduksi). Sasaran pengendalian proses statistik adalah mengurangi 
penyimpangan karena penyebab khusus dalam proses dan dengan mencapai stabilitas dalam proses. Penyelesaian masalah dengan statistik mencakup dua hal, seperti melebihi batas pengendalian bila proses dalam kondisi terkendali atau tidak melebihi batas pengendalian bila proses diluar kendali.

Pengendalian kualitas secara statistik dengan menggunakan SPC (Statistical Process Control) dan SQC (Statistical Quality Control), mempunyai 7 (tujuh) alat statistik utama yang dapat digunakan sebagai alat bantu untuk mengendalikan kualitas sebagaimana disebutkan juga oleh Heizer dan Render dalam bukunya Manajemen Operasi (2006:263-268), antara lain yaitu; check sheet, histogram, control chart, diagram pareto, diagram sebab akibat, scatter diagram dan diagam proses.

\subsection{Proses Kemunduran Mutu Ikan}

Ikan dikenal sebagai salah satu bahan makanan yang cepat mengalami kemunduran mutu hingga menjadi busuk. Sejak ikan ditangkap dari perairan, serangkaian perubahan-perubahan yang mengarah kepada pembusukan mulai terjadi. Hal ini karena segera setelah ikan mati, ikan akan mengalami proses enzimatis, bakteriologis, kimiawi dan fisik. Menurut Seagrant dalam Wiratama (2011), sewaktu ikan meronta pada saat di tangkap, ikan akan membentuk asam laktat yang menyebabkan ikan kelelahan sehingga dapat merusak jaringan. Rusaknya jaringan pada daging ikan akan menyebabkan warna daging yang semula cemerlang menjadi kusam, tekstur daging yang melunak, dan daging akan menjadi pahit. Bukan hanya pada saat ikan mengalami kelelahan, setelah mati suhu tubuh ikan akan mengalami kenaikan. Hal ini dapat mempercepat kemunduran mutu ikan dan memacu terjadinya pembusukan. Mengingat hal tersebut, maka setiap usaha meningkatkan produksi hasil perikanan harus disertai pula dengan upaya mempertahankan mutu ikan sebaik mungkin agar hasilnya dapat memberikan keuntungan baik bagi produsen (nelayan) maupun konsumen atau masyarakat.

\subsection{Penelitian Serupa yang Pernah Dilakukan Sebelumnya}

Penelitian Manajemen Mutu Terpadu khususnya mengenai pengendalian kualitas dengan menggunakan pendekatan Statistical Quality Control (SQC) untuk mengidentifikasi penyimpangan dalam proses produksi atau pengolahan telah 
dilakukan oleh peneliti-peneliti sebelumnya. Berikut merupakan beberapa penelitian terkait,meliputi :

Tabel 2.1 Penelitian Terdahulu

\begin{tabular}{|c|c|c|c|}
\hline Tahun & Peneliti & Judul Penelitian & Publikasi \\
\hline 2008 & Syaiful Bachri & $\begin{array}{lr}\text { Penerapan } & \text { Statistical } \\
\text { Quality } & \text { Control } \\
\text { Sebagai } & \text { Upaya } \\
\text { Implementasi } & \text { Metode } \\
\text { Six Sigma (Studi Kasus } \\
\text { PT Indonesia } & \text { Marine } \\
\text { Divisi Boiler) } & \end{array}$ & $\begin{array}{l}\text { E-Library Universitas } \\
\text { Brawijaya (Skripsi) }\end{array}$ \\
\hline 2015 & Zulfani Noor & $\begin{array}{l}\text { Analisis Pengendalian } \\
\text { Mutu Untuk Mencapai } \\
\text { Standar Kualitas } \\
\text { Produk Corn Chips Di } \\
\text { PT. Anugrah Cita Era } \\
\text { Food }\end{array}$ & $\begin{array}{l}\text { Repisotory Institut } \\
\text { Pertanian Bogor }\end{array}$ \\
\hline 2013 & Darsono & $\begin{array}{l}\text { Analisis Pengendalian } \\
\text { Kualitas Produksi } \\
\text { Dalam Upaya } \\
\text { Mengendalikan } \\
\text { Tingkat Kerusakan } \\
\text { Produk }\end{array}$ & $\begin{array}{ll}\text { Jurnal Ekonomi } & - \\
\text { Manajemen } & - \\
\text { Akuntansi } \\
\text { No. 35 / Th.Xx / } \\
\text { Oktober 2013 } \\
\text { ISSN:0853-8778 }\end{array}$ \\
\hline 2016 & $\begin{array}{l}\text { Kadek Putri Trisna } \\
\text { Devi, I Ketut Suamba, } \\
\text { Ni Wayan Putu Artini }\end{array}$ & $\begin{array}{l}\text { Analisis Pengendalian } \\
\text { Mutu Pada Pengolahan } \\
\text { Ikan Pelagis beku Di } \\
\text { PT Perikanan } \\
\text { Nusantara (Persero) } \\
\text { Cabang Benoa Bali }\end{array}$ & $\begin{array}{l}\text { E-Jurnal Agribisnis Dan } \\
\text { Agrowisata ISSN: } 2301- \\
6523 \text { Vol.5, No.1, } \\
\text { Januari } 2016\end{array}$ \\
\hline
\end{tabular}




\section{BAB 3}

\section{TUJUAN DAN MANFAAT PENELITIAN}

\subsection{Tujuan}

Tujuan dalam penelitian ini adalah untuk mengetahui pelaksanaan pengendalian mutu pada pengolahan Ikan Beby tuna beku apakah sudah berada pada batas kendali dengan menganalisis sistem pengendalian mutu untuk meminimumkan kerusakan pengolahan Ikan Beby tuna beku dengan pendekatan statistical quality control (SQC) pada PT. Abadi Makmur Ocean (AMO).

\subsection{Manfaat}

Berdasarkan tujuan penelitian di atas, penelitian ini diharapkan dapat memberikan manfaat secara teoritis maupun praktis. Secara teoritis, penelitian ini diharapkan dapat berkontribusi dalam penambahan kajian literature untuk pengembangan ilmu pengetahuan khususnya mengenai pengendalian kualitas atau mutu produk perikanan. Secara praktis, hasil penelitian ini diharapkan dapat membantu perusahaan dalam pegendalian kualitas produk mereka yang berorientasi ekspor sehingga dapat memberikan nilai tambah dan kepuasan pelanggan, yang berarti menambah profit atau laba dalam jangka pendek dan citra perusahaan menjadi lebih meningkat untuk jangka panjang. 


\section{BAB 4}

\section{METODE PENELITIAN}

\subsection{Lokasi dan Waktu Penelitian}

Penelitian dilaksanakan di PT Abadi Makmur Ocean (AMO)yang terletak di dalam wilayah Pelabuhan Perikanan Samudera (PPS) Kendari terletak di Kelurahan Puday, Kecamatan Abeli, Kota Kendari dan Provinsi Sulawesi Tenggara. Waktu penelitian dilaksanakan pada bulan September s.d. November tahun 2017.

\subsection{Data, Responden, Analisis Data}

Data kuantitatif yang dikumpulkan pada penelitian ini adalah jumlah produksi pengolahan jual Ikan Beby tuna beku ukuran $10 \mathrm{~kg}$ keatas komoditi ekspor pada bulan Oktober-November 2017, gaji karyawan pengawasan mutu (quality control), biaya jaminan mutu dalam pengolahan Ikan Beby tuna beku. Data kualitatif yang dicari mengenai situasi di PT AMO seperti gambaran tentang perusahaan, jenis produk yang dihasilkan, struktur organisasi perusahaan, dan pelaksanaan pengendalian mutu dalam pengolahan Ikan Beby tuna beku .

Teknik pemilihan responden dilakukan secara purposive yaitu lima orang responden yang dipilih secara sengaja dengan pertimbangan bahwa responden merupakan seseorang yang dianggap mengerti serta memahami mengenai manajemen keuangan, proses pengendalian mutu ikan, proses produksi penanganan dan pengolahan ikan Beby tuna beku, serta mutu ikan di PT AMO, sehingga mampu memberikan informasi sesuai dengan tujuan penelitian. Dengan demikian, peneliti memilih tiga orang karyawan dari perusahaan yang terdiri atas satu orang karyawan bagian pengendalian keuangan dan akuntansi perusahaan, satu orang karyawan bagian pengawasan mutu (quality control), satu orang bagian proses produksi penanganan dan pengolahan Ikan Beby tuna beku, serta dua orang mitra di PT AMO terdiri atas nelayan dan pedagang pengumpul.

Analisis data yang digunakan dalam penelitian ini yaitu analisis kualitatif dan analisis kuantitatif. Analisis kualitatif dilakukan melalui pendekatan deskriptif untuk mengetahui pelaksanaan pengendalian mutu pada pengolahan Ikan Beby tuna beku. Analisis kuantitatif digunakan untuk menganalisis sistem pengendalian mutu 
untuk meminimumkan kerusakan pengolahan Ikan Beby tuna beku menggunakan pendekatan statistical quality control (SQC) yaitu peta kendali (control chart) untuk mengetahui batasan pengawasan mutu dengan menggunakan metode Diagram Kendali P (P-chart) yang diolah melalui Software QM for Windows versi 5.2 pada Module Statistic Quality Control.). Prawirosentono dalam La Hatani (2007), peta kendali (control chart) adalah untuk membatasi toleransi penyimpangan (variasi) yang masih dapat diterima, baik karena akibat kelemahan tenaga kerja, mesin, dan sebagainya. Dalam statistik untuk memperoleh tingkat kepercayaan $99 \%$, maka batas toleransi \pm 3 standar penyimpangan dihitung dari standar ukuran. 


\section{BAB 5}

\section{HASIL DAN PEMBAHASAN}

\subsection{Sejarah Perusahaan}

PT. Abadi Makmur Ocean (PT. AMO) merupakan perusahaan yang dibangun oleh Pak Pieter Rusliem pada tanggal 28 Februari 2002. PT. AMO berinvestasi di bidang penampungan dan pengolahan ikan segar yang berada di PPS Kendari. Salah satu alasan Pak Pieter Rusliem melakukan investasi di bidang perikanan dengan mendirikan PT. AMO adalah karena Indonesia memiliki potensi yang besar dibidang perikanan khususnya daerah Sulawesi Tenggara yang sebagai salah satu sentra pensuplai ikan nasional. Awal pendrian perusahaan difasilitasi dan didukung oleh UD. Cahaya Bahari Nusantara dalam hal perizinan dan kepengurusan administrasi lainnya serta sumber permodalan. Prosedur pendirian perusahaan yang dialami oleh PT. AMO adalah dengan membuat akta notaris pendirian perusahaan (PT) kemudian mengajukan permohonan kepada Kementrian Perikanan yang difasilitasi oleh PPS Kendari ke Ditjen Perikanan Kementrian Perikanan Nasioanal. Selanjutnya setelah melalui seleksi dan analisis yang panjang dalam Ditjen Perikanan maka dikeluarkanlah SK kelayakan operasi bagi PT. AMO yang selanjutnya segala bentuk usaha awal difasilitasi dan didukung oleh PPS Kendari selaku mitra perusahaan di tingkat lokal.

PT AMO merupakan salah satu perusahaan perikanan yang bergerak dibidang penampungan dan pengolahan hasil perikan yang berada di PPS Kendari. PT AMO terletak di kavling-H dengan luas kavling dan termasuk bangunannya menurut data PPS Kendari 2013 seluas $4.500 \mathrm{~m}^{2}$. Perusahaan ini dipimpin oleh seorang manager yang juga merupakan anak dari pemilik perusahaan dan dibantu oleh seorang sekretaris yang bernama Fitri. Jenis ikan yang menjadi bahan baku untuk produksi PT. AMO adalah jenis Cakalang, Beby Tuna, Layang dan Deho. PT. AMO memiliki standar operasional kerja sesuai dengan ketentuan K3 dengan standar mutu hasil yang tinggi karena untuk di ekspor. Selanjutnya waktu kerja karyawan juga telah terjadwal bagi pekerja tetap dengan ada insentif untuk lembur dan tip perusahaan. PT. AMO mempekerjakan tenaga kerja tetap sebanyak 40 karyawan 
termasuk staf dan sekretaris dan lebih dari 50 orang tenaga kerja lepas yang hampir secara keseluruhan merupakan tenaga kerja lokal dengan dominasi tingkat pendidikan rendah (SMA) namun memiliki pengalaman dan keterampilan yang tinggi di bidang pengolahan ikan.

Bahan baku yang dibutuhkan oleh PT. AMO adalah berbagai jenis ikan laut lepas yang memiliki harga yang cukup tinggi di pasar baik domestic meupun mancanegara. Jenis ikan yang menjdi bahan baku PT. AMO bersal dari jenis Cakalang, Beby Tuna, Layang dan Deho dengan beragam ukuran. Jenis-jenis ikan ini diperoleh dair para nelayan tangkap yang beroperasi disekitar laut pesisir Kondari-Wawoni'i serta dari luar wilayah hingga Laut Sulawesi, laut Banda, Laut Maluku, dan Laut Arafuru.

Bahan baku perusahaan diperoleh hampir setiap hari dari para nelayan baik mitra perusahaan maupun bukan mitra. Suplai bahan baku berfluktuasi hampir setiap bulan tergantung dari banyaknya penangkapan nelayan dan keadaan gelombang laut. Puncak produksi PT. AMO bersamaan dengan puncak penangkapan ikan yang dilakukan oleh nelayan pada Bulan Desember-Maret dengan frekuensi penangkapan rata-rata sebesar 300 ton/bulan. Sementara suplai ikan normal terjadi pada Bulan April-Juni dan Oktober-November dengan frekuensi rata-rata penangkapan sebesar 100 ton/bulan. Sedangkan masa paceklik nelayan terjadi pada Bulan Juli-Juni dimana suplai ikan ke perusahaan sangat terbatas dan terkadang sepi. Beberapa hal yang menyebabkan kesulitan bagi nelayan untuk memperoleh penangkapan yang sesuai adalah karena perubahan peredaran bulan yang berpengaruh pada pola alur arus laut dan pola jelajah ikan serta keadaan cuaca ekstrim yang terjadi dengan kecepatan angin yang tinggi dan gelombang yang besar. Selain itu ketersediaan ikan di sekitaran pesisir Sulawesi Tenggara sudah mulai menurun akibat intensitas penangkapan yang terlalu tinggi,peraturan dari pemerintah mengenai penagkapan ikan serta perubahan pola perilaku ikan ikibat penangkapan yang mulai menjauh dari daratan memaksa nelayan untuk lebih memperluas daerah jelajahnya serta bila menginginkan penangkapan yang besar dalam satu kali pemancingan maka para nelayan melakukan perjalan yang jauh hingga Laut Arafuru untuk mencari ikan di sana. 
Nelayan yang melakukan penangkapan ikan membuat rumpon dilaut untuk tempat perkumpulan ikan dan pada saat-saat tertentu rumpon ini di dekati dan jala untuk mendapatkan ikannya. Ada beberapa pola kemitraan yang dibangun oleh para nelayan mengenai peningkatan jumlah tangkapan nelayan yaitu dengan membuat rumpon sendiri, menjaring rumpon milik perusahaan atau mencaring rumpon milik neyalan lokal. Pola kemitraan ini dibangun berdasarkan kepercayaan dan kepentingan untuk mencapai peningkatan ekonomi dan pendapatan rumahtangga nelayan lokal.

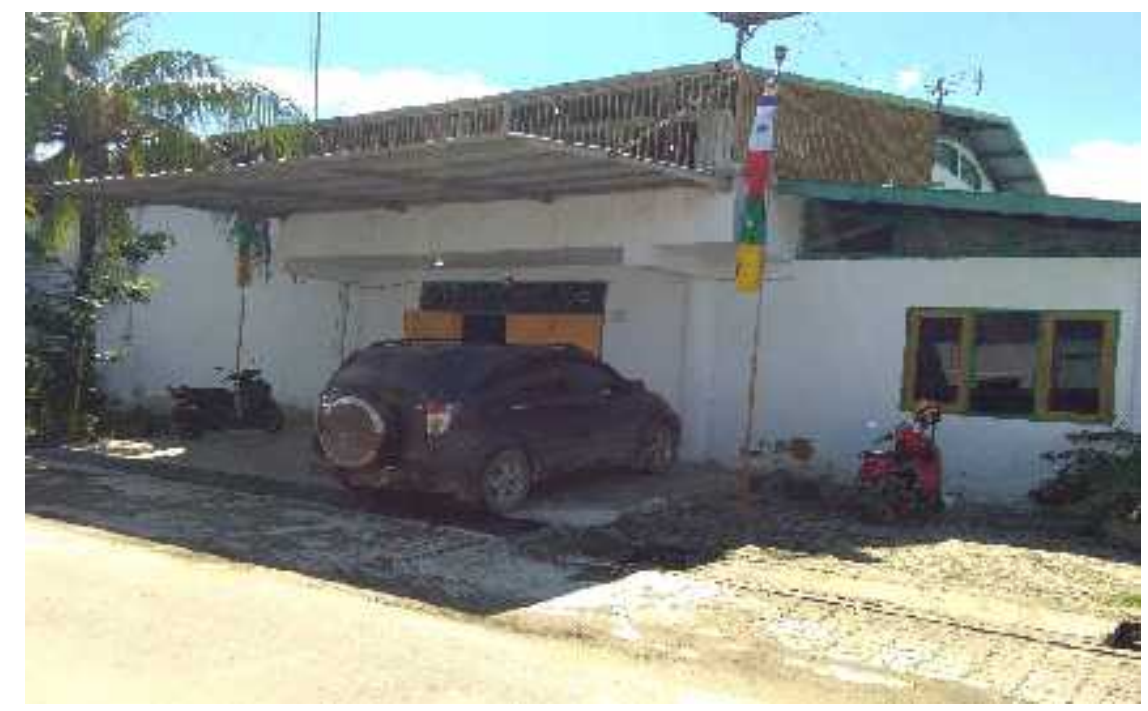

Gambar 5.1 Kantor PT Abadi Makmur Ocean (tampak depan)

PT. AMO yang melakukan kerja sama dengan beberapa perusahaan di Jakarta dan Surabaya dalam hal pemasaran dan pemberian nilai tambah komoditi sehingga lebih mudah diserap oleh pasar. PT. AMO hanya mengirimkan data jumlah produksi ikan yang mampu dihasilkan kepada perusahaan penada dan pengekpor dan kemudian mereka akan meminta sesuai kebutuhan mereka. Bila dilihat dari sisi pemasaran, strategi demikian tergolong sangat aman dan sederhana karena seluruh total produksi dapat terjual dan pengelola perusahaan tidak direpotkan dengan pembuatan dan pengurusan pemasaran hasil produksinya.

Salah satu perusahaan mitra yang berperan dalam mendistribusikan komoditi hasil produksi PT. AMO adalah UU. Cahaya Mandiri Nusantra yang merupakan kerabat dari pemilik PT. AMO. Selain itu ada beberpa perusahaan mitra PT. AMO dalam lingkup domestic maupun mancanegara dalam bidang pemasaran hasil yang 
berada di Jakarta, Surabaya, Manado, Taiwan, dan Thailand. Keberadaan perusahaan mitra ini sangat mendukung pertumbuhan PT. AMO karena melalui perusahaan mitra ini komoditi perikanan yang dihasilkan PT. AMO dapat terserap cepat oleh pasar sehingga keuntungan perusahaan bisa lebih besar dan produksi tetap lancar.

\subsection{Struktur Organisasi}

Dalam fungsi pongelolaan produksi hasil perikanan diperlukan tenaga kerja ahli dan terampil serta berfokus pada salah satu bidang sehingga target produksi yang telah dicanangkan dapat dicapai. Berdasarkan hasil wewancara mendalam dengan sekretaris PT. AMO diperoleh struktur organisasi perushaan dari tingkat atas ke bawah sebagai berikut:

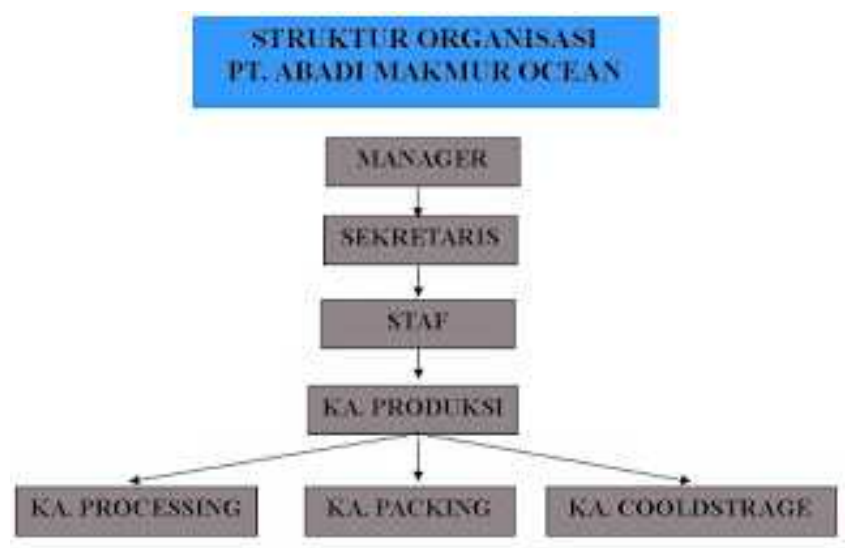

Gambar 5.2 Struktur Organisasi PT Abadi Makmur Ocean Kendari

Tenaga kerja yang bekerja dalam perusahaan PT. AMO terbagi atas beberapa tingkatan, yaitu setelah Manager perusahaan ada secretaries, kemudian dibantu oleh seorang staff yang mengontrol Ka. Produksi di lapangan. Pada bidang pengolahan di control oleh seorang Ka. Processing yang membawahi 50 karyawan pada puncak produksi dari tenaga kerja lepas dan tenaga kerja tetap harian. Sementra untuk bidang pengepakan di control oleh seorang Ka. Packing dengan anggota 10 karyawan pada saat produksi dan telah termasuk karyawan tetap karena standar pengepakan merupakan hal yang sangat penting dalam menjaga kualitas produk perusahaan. Dan dibidang pendinginan di kepalai oleh seorang Ka. Cooldstrage yang dibantu oleh 6 orang karyawan tetap dalam menjalankan peran dan fungsinya dalam perusahaan. 
Sebagai perusahaan besar yang bergerak dalam bidang penampungan dan pengolahan ikan segar hasil tangkapan nelayan, PT. AMO memiliki standat rekrut karyawan untuk masuk kedalam perusahaan. Berdasarkan keterangan yang diberikan oleh sekretaris Perusahaan, persyarakat masuk kedalam perusahaan tidak dibutuhkan standar pendidikan yang tinggi namun harus memiliki pengalam dalam pengolahan ikan dan kondisi fisik yang kuat karena dalam pabrik perusahaan pekerjaan yang dilakukan sebagaian besar merupakan pekerjaan berat yang membutuhkan tenaga ekstra. Gaji yang diberikan kepada karyawan khusunya dibagian pengawasan mutu adalah Rp 2.173.000 perbulan.

\subsection{Aspek Kemitraan Perusahaan}

PT. AMO melakukan kerja sama dengan bebera instansi dan stakeholder dalam mendukung kegiatan produksi dan memperlancar pemasaran komoditi yang dihasilkannya. Kemitraan yang dibangun oleh perusahaan dimulai dari nelayan, PPS Kendari, Perusahaan penyedia input, dan perusahaan distribusi pemasaran hasil. PT. AMO bermitra dengan nelayan dalam hal suplai bahan baku sehingga untuk tetap membuat nelayan turun melaut meskupin modal operasionalnya kecil, perusahaan memberikan pinjaman dana operasional pada para nelayan tergantung jenis kapal dan jenis ikan yang ditangkapnya. Untuk kapal penangkap jenis ikan cakalang dan beby tuna perusahaan memberikan pinjaman modal hingga Rp. 100 juta/unit dan untuk kepal penangkap ikan jenis Layang dan Deho perusahaan memberikan dana pinjaman sebesar Rp. 30 juta - Rp. 50 juta/unit. Pemberian pinjaman yang berbeda ini didasarkan atas perbedaan kebutuhan operasional kapal dan jumlah tangkapan ikan yang dapat disuplai ke perusahaan setaip mendarat.

Kemitraan yang penting berikutnya adalah dengan pihak pengurus pelabuhan PPS yang merupakan pengaur dan sentra informasi perikanan di Pelabuhan Samudra. PT. AMO melakukan kerja sama dengan PPS Kendari dalam hal pengontrolan kualitas ikan yang mendarat ke Pelabuhan Samudra yang nantinya akan didistribusikan ke perusahaan yang ada di dalam cakupan PPS Kendari, selain itu kerja sama berikutnya berikutnya berkenaan dengan pengelolaan perijinan dan operasionalisasi lainnya yang berkaitan dengan kegiatan produksi dan keamanan perusahaan di lokasi PPS Kendari. Dan mitra berikutnya adalah perusahaan penada hasil produksi ikan yang dihasilkan oleh PT. Abadi Makmur Ocean yaitu 
perusahaan distributor dan agroindustri perikanan lanjutan yang berada di Makassar, Surabaya, Jakarta dan beberapa kota besar lainnya dalam berperan dalam pemasaran hasil perikanan. Strategi kemitraan yang dibangun dengan membangun jaringan bisnis melalui relasi dan kemudian mempertahankan kepercayaan mitra perusahaan sehingga mitra perusahaan tetap loyal terhadap perusahaan.

\subsection{Pelaksanaan Pengendalian Mutu Pengolahan Ikan Beby Tuna Beku}

Kegiatan praproduksi dimulai pada saat ikan beby tuna didaratkan di atas Pelabuhan PPS Kendari dengan pegawai melakukan penyeleksian terhadap kelompok ikan beby tuna yang didaratkan, kelompok ikan beby tuna dalam boks yang kualitasnya tidak layak langsung dipisahkan. Selanjutnya ikan diperoleh dimuat dengan mobil untuk dibawa ke perusahaan. Pemindahan ikan beby tuna dari tempat transit ke dilakukan secara cepat menggunakan mobil untuk mencegah terjadinya peningkatan suhu tubuh ikan. Setelah tiba di perusahaan gebang perusahaan maka masuklah pada tahap produksi, ikan ikan beby dijemput oleh karyawan untuk selanjutnya dicuci, peralatan yang akan digunakan disiram dengan menggunakan air dingin dan akohol untuk meminimalisir kontaminasi bakteri. selanjutnya di bawa ke tempat penimbangan untuk diketahui berat dan kategori dari ukurannya seperti yang telah diterapkan oleh perusahaan. Tahap berikutnya ikan ikan beby yang telah di timbang tersebut kemudian dikemas dan dimasukan kedalam freezer untuk dibekukan selama beberapa saat menunggu ikan ikan beby yang sedang diolah sebelumnya habis. Setelah itu, ikan ikan beby diambil kembali untuk diadakan pengolahan dan kemudian dipacking dengan menggunakan karung yang beratnya untuk masing-masing karung mencapai $40 \mathrm{Kg}$. Setelah ikan beby tuna dipaking, untuk menunggu jumlah produksi yang sesuai jumlah penjualan maka ikan beby tuna yang dihasilkan di gudangkan selama beberapa waktu. Apabila kapal pengambil ikan beby tuna telah ada maka ikan beby tuna yang sudah digudang ini dikeluarkan kemudian didistribusikan melalui kapal ke konsumen yang membutuhkannya baik domsetik maupun mancanegara.

Aspek produksi sangat ditentukan oleh kualitas ikan beby tuna yang ditangkap oleh nelayan. Olehnya itu, pengontrolan terhadap kualitas ikan beby tuna dimulai sejak penangkapan oleh nelayan hingga pengiriman ke pihak yang 
membutuhkan ikan beby tuna yang dihasilkan harus ketat, namun yang mengambil peran besar dalam menjaga kualitas adalah perlakuan pada saat penangkapan dan penyimpanan di kapal nelayan. Ikan beby tuna yang telah layu dan cacat tidak dapat diterima oleh perusahaan lagi karena tidak sesuai dengan standar kualitas ekspor dan apabila tetap dipaksakan maka akan memperburuk citra perusahaan dimata mitra perusahaan dan konsumennya. Dalam menjaga kualitas ikan tetap terjaga PT AMO juga melakukan uji laboratorium setiap 6 bulan sekali, jadi dalam setahun uji laboratorium dilakukan 2 kali. Uji laboratorium dilakukan di Makassar dengan biaya pengetesan sebesar Rp 1.150.000.

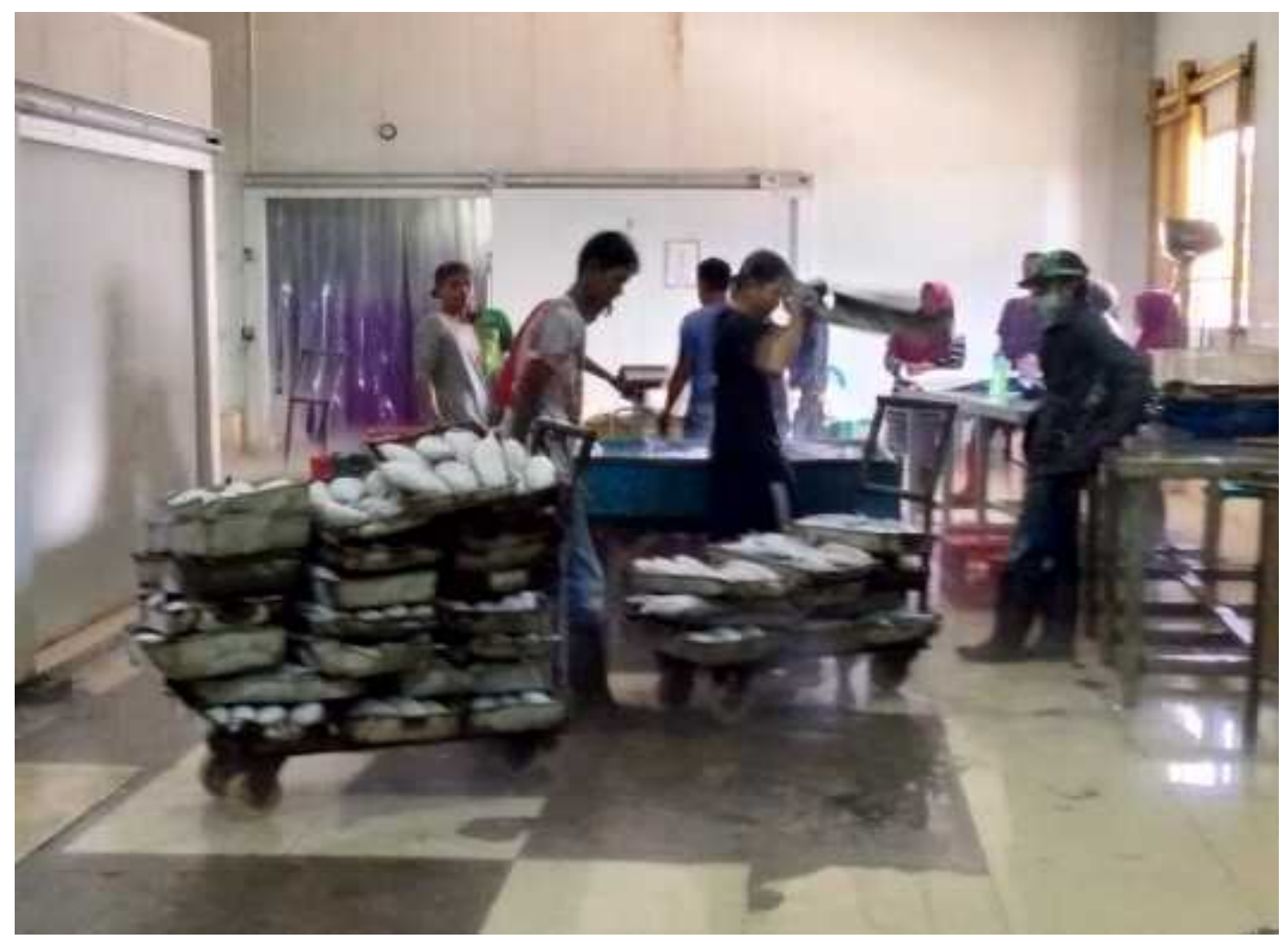

Gambar 5.3 Aktivitas Karyawan bagian Penyortiran dan Penyusunan Ikan Beby Tuna PT AMO

Menurut informasi dari nelayan yaitu aktivitas penangkapan di mulai dengan kapten kapal utama akan menyebar perahu-perahu pemancing. Tiap satu perahu pemancing terdiri oleh satu orang pemancing (nelayan). Kapten kapal yang berada di kapal utama akan menunggu nelayan pemancing selama operasi penangkapan dilakukan. Jika salah satu nelayan pemancing mendapatkan ikan beby tuna, maka kapal utama tersebut akan merapat ke perahu pemancing tersebut untuk membantu proses hauling. Proses hauling dilakukan di kapal utama karena perahu pemancing 
yang digunakan sangat kecil. Saat proses hauling dilakukan waktu yang digunakan cukup lama biasanya sekitar \pm 40 menit. Lamanya proses hauling ini disebabkan karena masih menggunakan tenaga manusia. Sistem penanganan ikan beby tuna segar nelayan memiliki cara penanganan sendiri berdasarkan atas pengalaman. Aktivitas penanganan ikan beby tuna yang dilakukan oleh nelayan di atas kapal utama adalah sebagai berikut:

1. Pembersihan dek kapal: Pada saat proses hauling sedang berlangsung, salah satu nelayan membersihkan dek kapal untuk untuk persiapan peletakan ikan beby tuna. Pembersihan dek kapal dilakukan dengan menggunakan air laut yang diambil dengan menggunakan ember lalu disiramkan ke dek kapal sampai di anggap bersih.

2. Persiapan alat bantu penanganan: Selain membersihkan dek kapal, pada saat itu juga nelayan tersebut telah menyiapkan alat bantu penanganan untuk mengangkat dan mematikan ikan beby tuna.

3. Ikan beby tuna ditahan dengan ganco: Saat ikan sudah berada di permukaan tepat di samping kapal, ikan tersebut langsung di ganco pada bagian insang dan pada bagian mulut.

4. Mematikan ikan: Bersamaan saat ikan beby tuna ditahan dengan ganco di permukaan tepat di samping kapal, ikan tersebut langsung dimatikan dengan menggunakan kayu pemukul.

5. Pelepasan mata pancing: Setelah ikan beby tuna dimatikan, nelayan melepaskan mata pancing yang masih melekat di mulut ikan beby tuna. Pelepasan mata pancing dilakukan nelayan dengan tangannya langsung (tanpa menggunakan alat bantu).

6. Ikan beby tuna dinaikkan ke atas kapal: nelayan menaikkan ikan beby tuna di atas kapal dengan menggunakan ganco sebagai alat bantu. Ikan beby tuna yang sudah diganco diangkat dan diletakkan di dek kapal.

7. Pendinginan awal: Ikan beby tuna diletakkan pada bagian atas wadah penyimpanan dalam keadaan belum tersusun rapi. Setelah itu nelayan kembali melakukan aktivitas pemancingan dengan menggunakan perahu pemancing.

8. Penyimpanan dalam wadah pendingin: Setelah waktu istrahat pemancingan tiba, barulah ikan beby tuna tersebut disusun dengan rapi dalam wadah 
pendingin. Penyusunan ikan dilakukan dengan cara berlapis-lapis yaitu es kemudian ikan beby tuna dan seterusnya pada bagian atas dilapisi dengan es.

9. Pembersihan alat dan area kerja: Setelah selesai proses penanganan ikan beby tuna dilakukan, nelayan membersihkan area kerja dan semua alat yang digunakan dengan air laut dan menyimpannya kembali ke tempatnya.

10. Pembongkaran ikan beby tuna: Setelah tiba di pangkalan, nelayan langsung melakukan pembongkaran.

\subsection{Sistem Pengendalian Mutu dengan Pendekatan Statistical Quality Control}

Proses produksi beby tuna segar dilakukan sesuai dengan jumlah yang dipesan oleh pelanggan. Hal ini dilakukan untuk mengurangi terjadinya penumpukan bahan baku dan penurunan mutu beby tuna yang dihasilkan karena bahan baku tuna yang diproduksi menjadi tidak segar. Pengukuran pengendalian mutu proses produksi beby tuna dilakukan pada rata-rata berat tuna segar gelondongan pada bulan Oktober 2017. Hasil pengukuran pengendalian mutu tersebut dapat dilihat pada table berikut.

Tabel 5.1 Hasil evaluasi rata-rata Beby Tuna pada bulan Oktober 2017 PT AMO

\begin{tabular}{|l|r|}
\hline Total Sample Size & 19446 \\
\hline Total Defects & 7870 \\
\hline Percentage defects & 0.40471 \\
\hline Std dev of p-bar & 0.01613 \\
\hline z value & 3 \\
\hline Upper Control Limit & 0.4531 \\
\hline Center Line & 0.40471 \\
\hline Lower Control Limit & 0.356321 \\
\hline
\end{tabular}

Sumber : Pengolahan Data

Berdasarkan table di atas, hasil pengolahan data menunjukan besarnya nilai garis sentral yaitu 0,40471 atau 40,47\%, nilai batas kendali atas (UCL) yaitu 0,4531 atau $45,31 \%$ yang berarti jika produk yang cacat/rusak mencapai atau berada di atas batas kendali atas (UCL) maka proses beby tuna yang dilakukan pada perusahaan dianggap tidak efektif. Sebaliknya produk cacat/rusak berada pada batas kendali bawah (LCL) menunjukan nilai sebesar 0,3563 atau 35,63\% berarti proses produksi beby tuna menunjukan cukup efektif. Mengacu dari hasil perhitungan di atas, maka 
tingkat cacat/kerusakan ikan beby tuna yang diproduksi PT AMO Kendari dengan menggunakan p-chart yang diolah melalui Software QM for Windows dapat diilustrasikan pada gambar berikut :

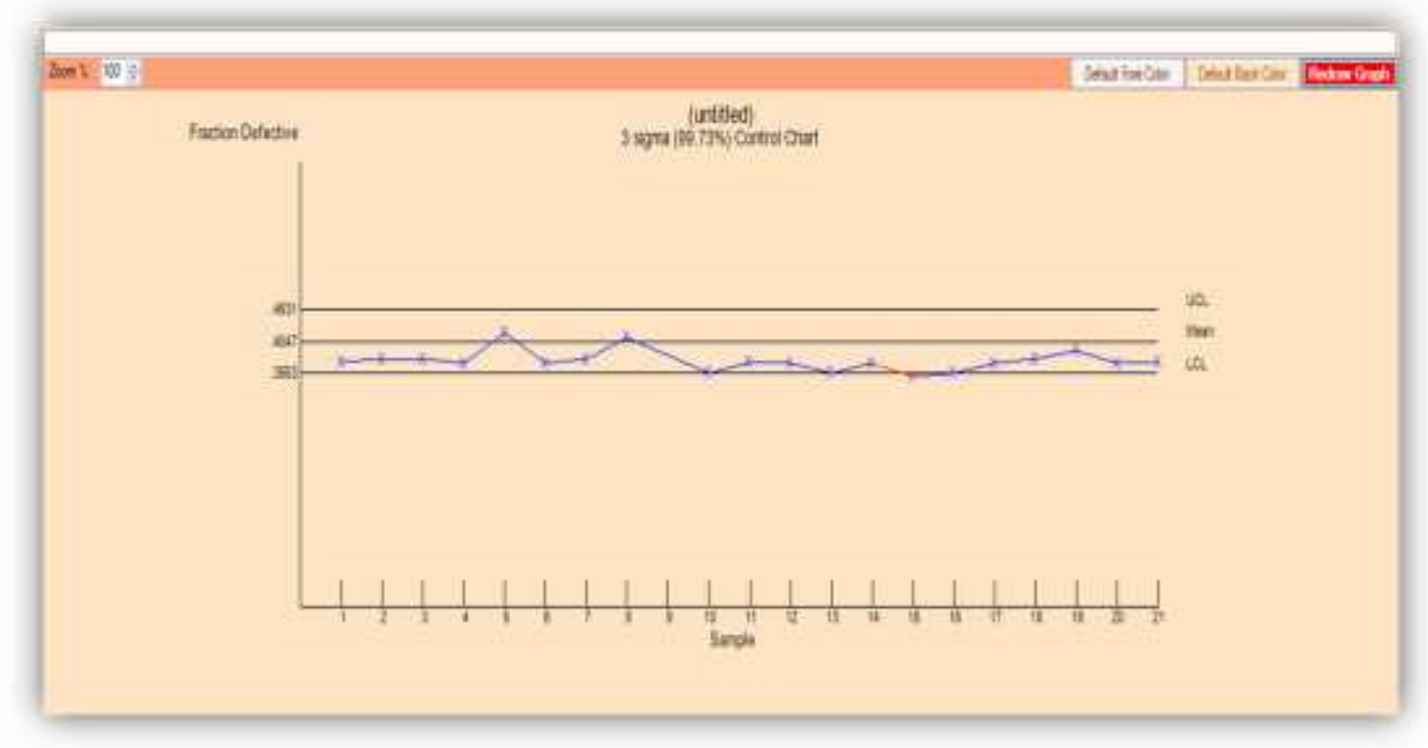

Gambar 5.4 Diagram Kendali P (P-charts) Untuk Jenis Beby Tuna

Berdasarkan peta kendali pada Gambar 5.3 , nilai rata-rata produksi berat beby tuna segar adalah 40,47 $\mathrm{kg}$ dan nilai batas kontrol atas (UCL) sebesar 45,31 $\mathrm{kg}(x<\mathrm{UCL})$, serta nilai batas spesifikasi bawah (LSL) sebesar 35,63 $\mathrm{kg}(x>\mathrm{LSL})$. Secara umum dapat dilihat bahwa kondisi ikan beby tuna masih sesuai dengan kondisi bahan baku yang diharapkan perusahaan, hanya satu yang diluar batas kendali yaitu pada hari ke 15 . Hal seperti ini dihasilkan akibat variasi penyebab khusus (special cause effect) yang dapat bersumber dari faktor-faktor, seperti: manusia, peralatan, material, lingkungan, dan metode kerja (Gaspersz 2003).

\subsection{Pengamatan Kondisi Sanitasi Higiene dan Lingkungan pada PT Abadi Makmur Ocean (AMO)}

Tabel 5.2 Kondisi Sanitasi Higiene dan Lingkungan pada PT Abadi Makmur Ocean (AMO)

\begin{tabular}{|c|c|c|c|}
\hline \multirow{2}{*}{ No } & URAIAN & \multicolumn{2}{|c|}{ KONDISI } \\
\cline { 3 - 4 } & Sesuai & $\begin{array}{c}\text { Tidak } \\
\text { Sesuai }\end{array}$ \\
\hline 1. & Lokasi & $\sqrt{ }$ & \\
\hline & $\begin{array}{l}\text { Tidak berada di tempat yang merupakan daerah } \\
\text { buangan kotoran dan sampah atau daerah lain } \\
\text { - yang diduga dapat menim } \text { bulkan pencemaran }\end{array}$ & $\sqrt{ }$ & \\
\hline
\end{tabular}




\begin{tabular}{|c|c|c|}
\hline & $\begin{array}{l}\text { Bebas dari tempat timbunan barang bekas yang } \\
\text { tidak teratur } \\
\text { - Ketersediaan jalan dan fasilitas lainnya untuk } \\
\text { mendukung kelancaran arus distribusi ikan } \\
\text { - Ketersediaan air bersih, tempat pembuangan } \\
\text { - } \quad \text { Lampah, bahan bakar dan listrik } \\
\text { - }\end{array}$ & $\begin{array}{l}\sqrt{ } \\
\sqrt{ } \\
\sqrt{ }\end{array}$ \\
\hline 2. & Konstruksi & \\
\hline & 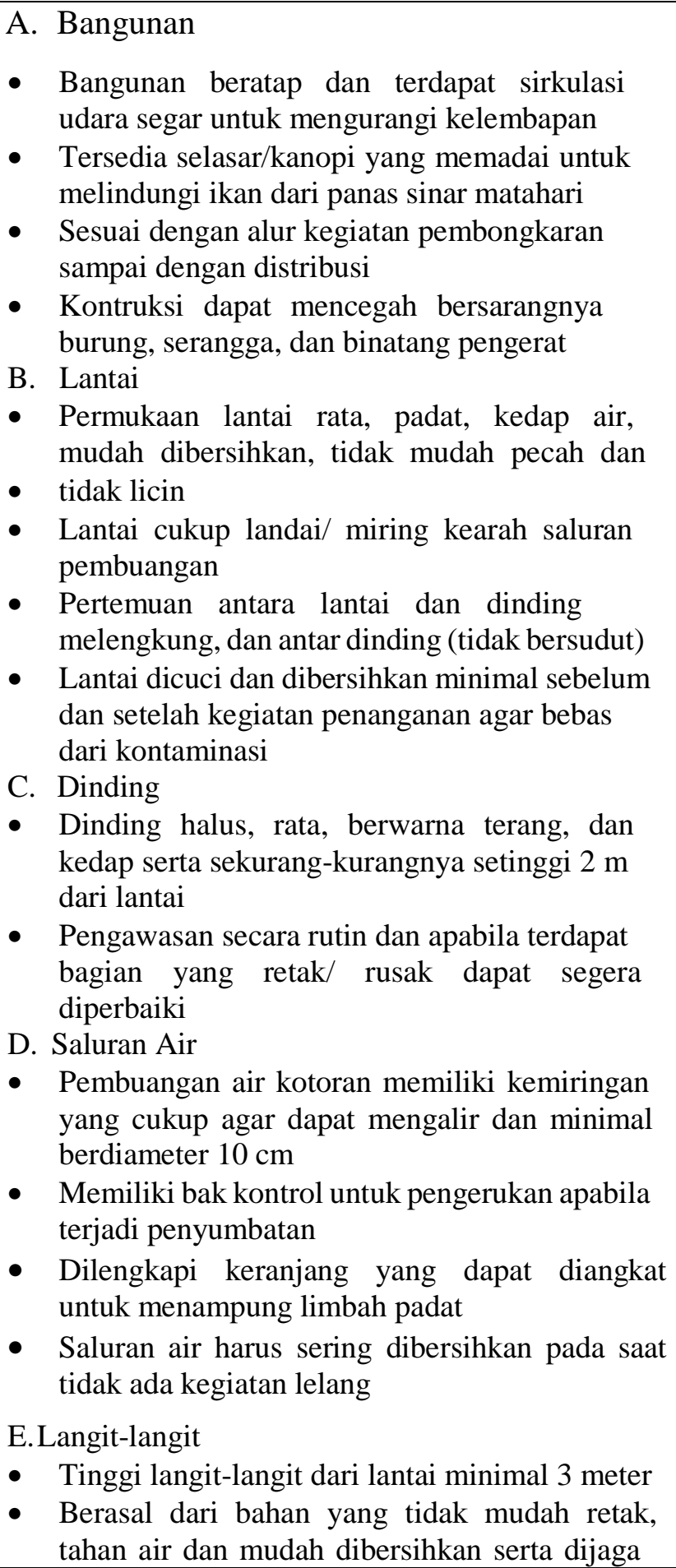 & $\begin{array}{l}\sqrt{ } \\
\sqrt{ } \\
\sqrt{ } \\
\sqrt{ } \\
\sqrt{ }\end{array}$ \\
\hline
\end{tabular}




\begin{tabular}{|c|c|c|}
\hline & $\begin{array}{l}\text { atau dipelihara dari terjadinya keretakan } \\
\text { - Program pembersihan, perbaikan dan } \\
\text { pelaksanaannya } \\
\text { F. Penerangan } \\
\text { - Penerangan yang cukup baik alami ataupun } \\
\text { menggunakan lampu } \\
\text { - Berpelindung dan program pengecekan } \\
\text { terhadapa instalasi listrik dan pembersihan } \\
\text { - terhadap lampu dari kotoran dan debu } \\
\text { G.Fasilitas Sanitasi } \\
\text { - Tersedia toilet yang memadai } \\
\text { - Toilet terpisah dari tempat penanganan dan } \\
\text { atau penjualan ikan } \\
\text { - Toilet tertutup dan dilengkapi dengan fasilitas } \\
\text { air bersih dan disinfektan } \\
\text { Tersedia tempat cuci tangan dan dilengkapi } \\
\text { bahan pencuci tangan (sabun) dan pengering } \\
\text { sekali pakai dan bak cuci kaki } \\
\text { - Program pembersihan dan perawatan }\end{array}$ & $\begin{array}{l}\sqrt{ } \\
\sqrt{ } \\
\sqrt{ } \\
\sqrt{ } \\
\sqrt{ } \\
\sqrt{ } \\
\sqrt{ } \\
\sqrt{ }\end{array}$ \\
\hline 3. & Fasilitas Pendukung & \\
\hline & $\begin{array}{l}\text { - Es terbuat dari air yang memenuhi persyaratan } \\
\text { air minum } \\
\text { - Persyaratan mutu es : } \\
\text { - Organoleptik: Tidak berbau, tidak berasa dan } \\
\text { tidak berwarna } \\
\text { - Kebutuhan es disesuaikan dengan rata-rata } \\
\text { volume produksi ikan yang didaratkan/ } \\
\text { dipasarkan } \\
\text { - Pasokan air cukup dan memenuhi persyaratan } \\
\text { air minum }\end{array}$ & $\begin{array}{l}\sqrt{ } \\
\sqrt{ } \\
\sqrt{ }\end{array}$ \\
\hline 4 & Peralatan & \\
\hline & $\begin{array}{l}\text { - Peralatan tidak digunakan untuk tujuan lain } \\
\text { - Timbangan terbuat dari bahan yang tahan } \\
\text { karat, tidak mengelupas dan tidak mudah } \\
\text { dipindahkan } \\
\text { - Timbangan harus dikalibrasi secara periodik } \\
\text { - Peralatan yang digunakan terbuat dari bahan } \\
\text { yang tidak mengkontaminasi ikan } \\
\text { - Alat angkut yang digunakan untuk } \\
\text { memindahkan ikan harus dapat melindungi } \\
\text { ikan dari kontaminasi dan kenaikan suhu } \\
\text { - Wadah ikan dibersihkan dan dibilas dengan air } \\
\text { bersih atau air laut bersih } \\
\text { Dilengkapi dengan tanda peringatan dilarang } \\
\text { merokok, meludah, makan, minum dan } \\
\text { diletakkan di tempat yang mudah dilihat dengan } \\
\text { jelas }\end{array}$ & $\begin{array}{l}\sqrt{ } \\
\sqrt{ } \\
\sqrt{ }\end{array}$ \\
\hline
\end{tabular}




\begin{tabular}{|l|l|l|l|}
\hline$\bullet \begin{array}{l}\text { Mempunyai wadah khusus yang tahan karat } \\
\text { dan kedap air untuk menampung hasil } \\
\text { perikanan yang tidak layak untuk dimakan }\end{array}$ & $\sqrt{ }$ & \\
\hline
\end{tabular}

Pengamatan Kondisi Sanitasi Higiene dan Lingkungan pada PT Abadi Makmur Ocean (AMO) secara keseluruhan kondisinya sudah sesuai dengan standar pengendalian mutu dan keamanan hasil perikanan di sentra penyedia pangan sehat yang di terapkan oleh Badan Karantina Ikan, Pengendalian Mutu Dan Keamanan Hasil Perikanan Selaku Otoritas Kompeten. 


\section{BAB 6}

\section{KESIMPULAN DAN SARAN}

\subsection{Kesimpulan}

Dari hasil penelitian, maka dapat ditarik kesimpulan sebagai berikut:

1. Hasil analisis Statistical Quality Control (SQC) dengan metode diagram kendali $\mathrm{P}$ (P-charts) diketahui bahwa tingkat pencapaian standar yang diharapkan oleh perusahaan sudah tercapai. Hal ini terbukti dari hasil pemeriksaan sampel ikan beby tuna komoditas ekspor pada bulan oktober 2017 dengan 21 hari kerja, hanya satu hari yaitu hari ke 15 jumlah produk yang mengalami kerusakan karena berada diluar batas pengawasan kualitas atau terjadi penyimpangan kualitas.

2. Pelaksanaan Pengendalian Mutu Pengolahan Ikan Beby Tuna pada PT. sudah memiliki standar operasional kerja sesuai dengan ketentuan K3 dengan standar mutu hasil yang tinggi karena untuk di ekspor.

3. Pengamatan Kondisi Sanitasi Higiene dan Lingkungan pada PT Abadi Makmur Ocean (AMO) secara keseluruhan kondisinya sudah sesuai dengan standar pengendalian mutu dan keamanan hasil perikanan di sentra penyedia pangan sehat yang di terapkan oleh Badan Karantina Ikan, Pengendalian Mutu Dan Keamanan Hasil Perikanan Selaku Otoritas Kompeten.

\subsection{Saran}

Pengendalian mutu pada produksi ikan beby tuna dengan pendekatan statistical quality control memerlukan keterlibatan aktif pada tim manajemen. Diharapkan dengan hasil penelitian ini dapat menjadi acuan buat perusahaan agar tetap mempertahankan pengawasan kualitas mutu sehingga kepuasan konsumen dan citra perusahaan bisa ditingkatkan sebab dengan adanya batas toleransi antara spesifikasi berat produk dengan batas kendali pada peta kendali mutu dilakukan sebagai acuan berat produk untuk mengurangi variasi dan peningkatan nilai kapabilitas proses. 


\section{DAFTAR PUSTAKA}

Al Fakhri,Faiz. 2010, Analisis Pengendalian Kualitas Produksi di PT. Masscom Grahpy Dalam Upaya Mengendalikan Tingkat Kerusakan Produk Menggunakan Alat Bantu Statistik. Skripsi. Fakultas Ekonomi Universitas Diponegoro, Semarang.

Bachri, Syaiful. 2008. Penerapan Statistical Quality Control Sebagai Upaya Implementasi Metode Six Sigma (Studi Kasus PT Indonesia Marine Divisi Boiler). Skripsi. Fakultas Tekhnik Jurusan Mesin Universitas Brawijaya, Malang.

Berita Antara Sultra, 2014. Perkuat Stabilitas Perikanan, KKP Jalankan SLIN, di Akses tanggal 20 Agustus 2017, http://www.antarasultra.com/,2016.

Darsono, 2013. Analisis Pengendalian Kualitas Produksi Dalam Upaya Mengendalikan Tingkat Kerusakan Produk, Jurnal Ekonomi - Manajemen - Akuntansi, No. 35 / Th.XX / Oktober 2013. ISSN:0853-8778

Devi, Kadek Putri Trisna., Suamba I Ketut., Artini Ni Wayan Putu., 2016. Analisis Pengendalian Mutu Pada Pengolahan Ikan Pelagis beku Di PT Perikanan Nusantara (Persero) Cabang Benoa Bali. E-Jurnal Agribisnis Dan Agrowisata Vol.5, No.1, Januari 2016, ISSN: 2301-6523

Gasperz, Vincent. 2005. Total Quality Management. Jakarta : PT. Gramedia Pustaka Utama.

Hatani, La. 2008. "Manajemen Pengendalian Mutu Produksi Roti Melalui Pendekatan Statistical Quality Control (SQC)." Diakses 20 Agustus 2017, dari www.google.com/Jurusan Manajemen FE Unhalu.

Heizer, Jay and Barry Render. 2006. Operations Management (Manajemen Operasi). Jakarta : Salemba Empat.

Hutagalung, Saut, 2014. Empat Tantangan Industri Perikanan Jelang MEA 2015, di akses tanggal 22 Agustus 2017, www.bisnis.com

Noor, Zulfani. 2015. Analisis Pengendalian Mutu Untuk Mencapai Standar Kualitas Produk Corn Chips Di PT. Anugrah Cita Era Food. Skripsi. Fakultas Ekonomi dan Manajemen Institut Pertanian Bogor, Bogor.

Perikanan Indonesia, 2011. Prospek perikanan Indonesia, di akses tanggal 23 Agustus 2017, www.prospekperikananindonesiasma4.weebly.com

Prawirosentono, Suyadi. 2007. Filosofi Baru Tentang Manajemen Mutu Terpadu Abad 21 "Kiat Membangun Bisnis Kompetitif". Jakarta : Bumi Aksara. 
Wiratama, Bayu, 2011. Kelayakan Ikan Tuna Untuk Tujuan Ekspor Pada Kegiatan

Penangkapan Menggunakan Pancing Tonda Di Sadeng Yogyakarta.

Skripsi. Fakultas Perikanan Dan Ilmu Kelautan. Institut Pertanian Bogor. 


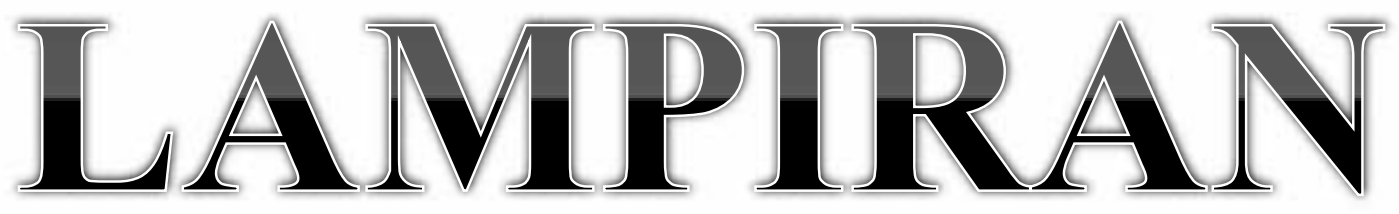




\section{Lampiran 1 Susunan Organisasi Tim Pengeusul dan Pembagian Tugas}

\begin{tabular}{|l|l|l|l|l|l|}
\hline No & Nama/NIDN & Instansi Asal & Bidang Ilmu & Alokasi Waktu & (Jam/Minggu) \\
\hline 1 & Riski Amalia Madi, SE,. M.Si/ 0010038006 & Universitas Halu Oleo & Manajemen Operasional & 3 & Ketua Penelitian dan Pengolah Data \\
\hline 2 & Neneng Lagatari, SE,. M.Si./ 0018017908 & Universitas Halu Oleo & Manajemen Keuangan & 3 & Dokumentasi dan kolektor Data \\
\hline
\end{tabular}




\section{Lampiran 2 Surat Pernyataan Ketua Pelaksana}

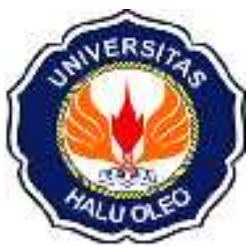

\section{KEMENTERIAN RISET, TEKNOLOGI DAN PENDIDIKAN TINGGI UNIVERSITAS HALU OLEO LEMBAGA PENELITIAN DAN PENGABDIAN MASYARAKAT (LPPM)}

Alamat : Gedung Rektorat Lt 1 Kampus Hijau Bumi Tridharma Jl. HEA Mokodompit Kendari 93232.

Telp/Fax (0401) 319339, E-mail : 1ppmuho@yahoo.com-1ppm@uho.ac.id Website :www.lppm.uho.ac.id

\section{SURAT PERNYATAAN KETUA PENELITI}

Yang bertanda tangan dibawah ini:

Nama

: Riski Amalia Madi, SE,. M.Si

NIDN

: 0010038006

Pangkat / Golongan : Penata Muda Tk.I/III b

Jabatan Fungsional : :

Dengan ini menyatakan bahwa Penelitian saya dengan judul:

\section{ANALISIS PENGENDALIAN MUTU PENGOLAHAN IKAN BABY TUNA BEKU}

PADA PT ABADI MAKMUR OCEAN KENDARI yang diusulkan dalam skema Dana

Hibah Penelitian Dosen Pemula untuk tahun anggaran 2017 bersifat original dan belum pernah dibiayai oleh lembaga/sumber dana lain.

Bilamana di kemudian hari ditemukan ketidaksesuaian dengan pernyataan ini, maka saya bersedia dituntut dan diproses sesuai dengan ketentuan yang berlaku dan mengembalikan seluruh biaya penugasan yang sudah diterima ke Kas Negara.

Demikian pernyataan ini dibuat dengan sesungguhnya dan dengan sebenar-benarnya.

Mengetahui,

Ketua Lembaga Penelitian/Pengabdian,

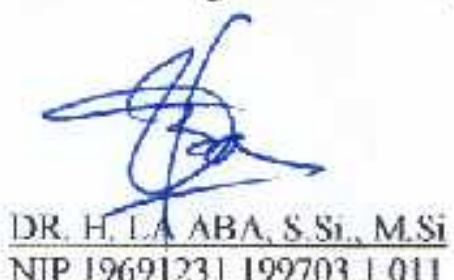

Kendari, 30 November 2017

Yang menyatakas,

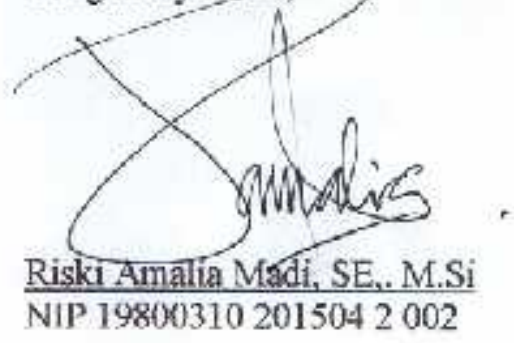




\section{Lampiran 3 Biodata Ketua dan Anggota Tim Pengusul}

A. Identitas Diri Ketua Pengusul

\begin{tabular}{|c|c|c|}
\hline 1 & Nama Lengkap & Riski Amalia Madi, SE, M.Si \\
\hline 2 & Jenis Kelamin & Perempuan \\
\hline 3 & Jabatan Fungsional & Tenaga Pendidik \\
\hline 4 & NIP & 198003102015042002 \\
\hline 5 & NIDN & 0010038006 \\
\hline 6 & Tempat dan Tanggal Lahir & Wakatobi, 10 Maret 1980 \\
\hline 7 & E- mail & riski_amalia98@yahoo.com \\
\hline 8 & Nomor HP & 081341507556 \\
\hline 9 & Alamat Kantor & Kampus Hijau Bumi Tridharma Andonohu \\
\hline 10 & Lulusan yang Telah dihasilkan & S-1 =2 orang \\
\hline 11 & Mata Kuliah yang diampuh & $\begin{array}{l}\text { 2. Statistik Ekonomi dan Bisnis } \\
\text { 3. Matematika Ekonomi dan Bisnis } \\
\text { 4. Manajemen Operasiona } \\
\text { 5. Sistem Informasi Mnajemen } \\
\text { 6. Manajemen Resiko } \\
\text { 7. Ekonomi Manajerial } \\
\text { 8. Riset Operasi } \\
\text { 9. Perpajakan }\end{array}$ \\
\hline
\end{tabular}

B. Riwayat Pendidikan

\begin{tabular}{|c|c|c|}
\hline & S-1 & S-2 \\
\hline Nama Perguruan Tinggi & Universitas Halu Oleo & Universitas Hasanuddin \\
\hline Bidang Ilmu & Manjemen & Manajemen dan Keuangan \\
\hline Tahun Masuk - Lulus & $1998-2002$ & $2006-2008$ \\
\hline Judul Skripsi & $\begin{array}{l}\text { Pengawasan Kualitas } \\
\text { Pelayanan Pada AJB Bumi } \\
\text { Putera Cabang Kendari }\end{array}$ & $\begin{array}{lr}\text { Pengaruh } & \text { Bantuan } \\
\text { Terhadap Kewirausahaan } & \text { Dan } \\
\text { Kinerja Usaha Mikro Sektor } & \text { Serdagangan Di Kota Kendari }\end{array}$ \\
\hline Nama Pembimbing & $\begin{array}{l}\text { La Ode Syaefuddin, SE, M.Si } \\
\text { Muh.Taufik,SE, M.Si }\end{array}$ & $\begin{array}{l}\text { Prof.DR. Djabir Hamzah, SE, MA } \\
\text { Prof. DR. H. Osman Lewangka, } \\
\text { SE, MA }\end{array}$ \\
\hline
\end{tabular}


C. Pengalaman Penelitian

\begin{tabular}{|c|c|l|}
\hline No & Tahun & \multicolumn{1}{|c|}{ Judul Penelitian } \\
\hline 1 & 2015 & Model \\
\hline 2 & 2015 & $\begin{array}{l}\text { Kegiatan } \\
\text { Pemberdayaan Anak Jalanan } \\
\text { Kota Kendari }\end{array}$ \\
\hline
\end{tabular}

D. Pengalaman Pengabdian Kepada Masyarakat

\begin{tabular}{|c|c|l|}
\hline No & Tahun & \multicolumn{1}{|c|}{$\begin{array}{l}\text { Judul Pengabdian Pada } \\
\text { Masyarakat }\end{array}$} \\
\hline \multirow{2}{*}{1} & 2015 & $\begin{array}{l}\text { Upaya Penanggulangan } \\
\text { Penyediaan Air Bersih } \\
\text { Daerah Pesisir Kecamatan } \\
\text { Wakorumba C Utara } \\
\end{array}$ \\
& Kabupaten Buton Utara \\
\hline
\end{tabular}

Semua data yang saya isikan dan tercantum dalam biodata ini adalah benar dan dapat dipertanggungjawabkan secara hukum. Apabila di kemudian hari ternyata dijumpai ketidak- sesuaian dengan kenyataan, saya sanggup menerima sanksi. Demikian biodata ini saya buat dengan sebenarnya untuk memenuhi salah satu persyaratan dalam pengajuan Penugasan Penelitian Dana Hibah Dosen Pemula

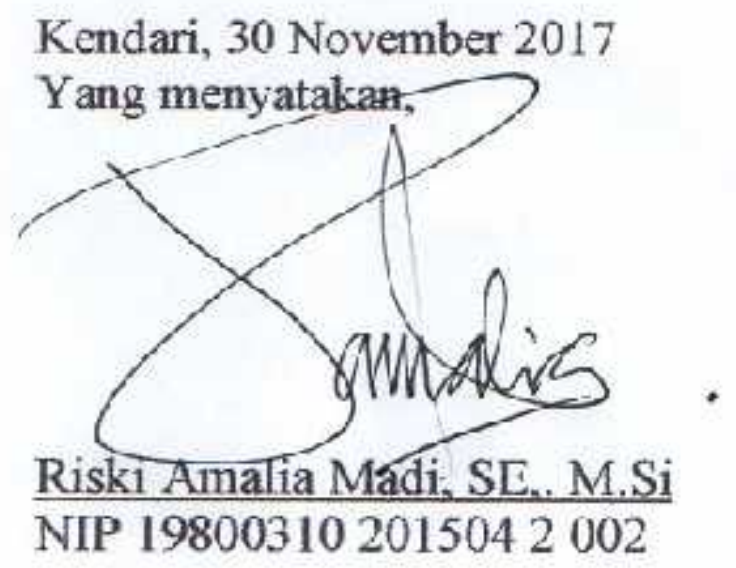


A. Identitas Diri Anggota

\begin{tabular}{|c|c|c|}
\hline 1 & Nama Lengkap & Neneng Lagatari, SE, M.Si \\
\hline 2 & Jenis Kelamin & Perempuan \\
\hline 3 & Jabatan Fungsional & Tenaga Pendidik Non PNS \\
\hline 5 & NIDN & 0018017908 \\
\hline 6 & Tempat dan Tanggal Lahir & Jakarta, 18 Januari 1979 \\
\hline 7 & E- mail & 123nilagatari@gmail.com \\
\hline 8 & Nomor HP & 085341511102 \\
\hline 9 & Alamat Kantor & $\begin{array}{l}\text { Kampus Pasca Sarjana Abdullah Silondae, Jl. } \\
\text { Mayjend S.Parman Kel. Kemaraya Kendari, } \\
93121\end{array}$ \\
\hline 11 & Mata Kuliah yang diampuh & $\begin{array}{ll}\text { 1. } & \text { Manajemen Resiko } \\
\text { 2. } & \text { Manajemen Keuangan } \\
\text { 3. } & \text { Perpajakan } \\
\text { 4. } & \text { Akuntansi Manajemen } \\
\text { 5. } & \text { Pengantar Akuntantansi } \\
\text { 6. } & \text { Akuntansi Biaya } \\
\text { 7. } & \text { Manajemen Perbankan }\end{array}$ \\
\hline
\end{tabular}

B. Riwayat Pendidikan

\begin{tabular}{|l|l|l|}
\hline & \multicolumn{1}{|c|}{ S-1 } & \multicolumn{1}{c|}{ S-2 } \\
\hline Nama Perguruan Tinggi & Universitas Halu Oleo & Universitas Halu Oleo \\
\hline Bidang Ilmu & Akuntansi & Manajemen \\
\hline Tahun Masuk - Lulus & $1997-2002$ & $2010-2013$ \\
\hline Judul Skripsi & $\begin{array}{l}\text { Prosedur Pencatatan Akuntansi } \\
\text { Pada Perum Pegadaian Cabang } \\
\text { Kendari }\end{array}$ & $\begin{array}{l}\text { Pengaruh Lingkungan Usaha, Sumber } \\
\text { Daya Finansial dan Kompetensi } \\
\text { Pengelola Kinerja UKM di Kota } \\
\text { Kendari }\end{array}$ \\
\hline Nama Pembimbing & $\begin{array}{l}\text { DR. Syamsiar Bahtiar, SE, M.Si } \\
\text { DR. Muntu Abdullah,SE, M.Si, Ak }\end{array}$ & $\begin{array}{l}\text { Prof.DR.Murdjani K, SE, M.Si } \\
\text { DR. Sujono, SE, M.Si }\end{array}$ \\
\hline
\end{tabular}

Semua data yang saya isikan dan tercantum dalam biodata ini adalah benar dan dapat dipertanggungjawabkan secara hukum. Apabila di kemudian hari ternyata dijumpai ketidak- sesuaian dengan kenyataan, saya sanggup menerima sanksi.

Demikian biodata ini saya buat dengan sebenarnya untuk memenuhi salah satu persyaratan dalam pengajuan Penugasan Penelitian Dana Hibah Dosen Pemula

Kendari, 30 November 2017

Aggota,

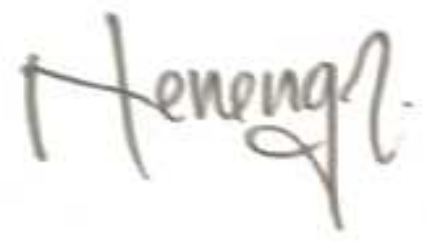

Neneng Lagatari, SE, M.S 


\title{
Lampiran 4. Draft Artikel Publikasi Penelitian
}

\section{ANALISIS PENGENDALIAN MUTU PENGOLAHAN IKAN BEBY TUNA BEKU PADA PT ABADI MAKMUR OCEAN KENDARI}

\author{
Riski Amalia Madi ${ }^{1}$, Neneng Lagatari ${ }^{2}$ \\ ${ }^{1}$ Universitas Halu Oleo \\ ${ }^{2}$ Universitas Halu Oleo \\ E-mail: ${ }^{1}$ riski_amalia98@yahoo.com, ${ }^{2}$ 123nilagatari@gmail.com
}

\begin{abstract}
Abstrak
Tujuan dalam penelitian ini adalah untuk mengetahui pelaksanaan pengendalian mutu pada pengolahan Ikan Beby tuna beku apakah sudah berada pada batas kendali dengan menganalisis sistem pengendalian mutu untuk meminimumkan kerusakan pengolahan Ikan Beby tuna beku dengan pendekatan statistical quality control (SQC) pada PT. Abadi Makmur Ocean (AMO). Hasil analisis Statistical Quality Control (SQC) dengan metode diagram kendali P ( $P$ charts) menunjukan besarnya nilai garis sentral yaitu 0,40471 atau $40,47 \%$, nilai batas kendali atas (UCL) yaitu 0,4531 atau $45,31 \%$ yang berarti jika produk yang cacat/rusak mencapai atau berada di atas batas kendali atas (UCL) maka proses beby tuna yang dilakukan pada perusahaan dianggap tidak efektif, sebaliknya produk cacat/rusak berada pada batas kendali bawah (LCL) menunjukan nilai sebesar 0,3563 atau $35,63 \%$ berarti proses produksi beby tuna menunjukan cukup efektif. Hal ini terbukti dari hasil pemeriksaan sampel ikan beby tuna komoditas ekspor pada bulan Oktober-November 2017 dengan 21 hari kerja, hanya satu hari yaitu hari ke 15 jumlah produk yang mengalami kerusakan karena berada diluar batas pengawasan kualitas atau terjadi penyimpangan kualitas. Kondisi sanitasi higiene dan lingkungan pada PT AMO secara keseluruhan kondisinya sudah sesuai dengan standar pengendalian mutu dan keamanan hasil perikanan di sentra penyendia pangan sehat yang di terapkan oleh Badan Karantina Ikan, Pengendalian Mutu Dan Keamanan Hasil Perikanan Selaku Otoritas Kompeten.
\end{abstract}

Kata Kunci: Pengawasan Mutu, Statistical Quality Control, Sanitasi Higiene dan Lingkungan 


\section{Pendahuluan}

Indonesia sebagai negara kepulauan terbesar di dunia memiliki laut yang luasnya sekitar 5,8 juta $\mathrm{km}^{2}$ dan menurut World Resources Institute tahun 1998 memilki garis pantai sepanjang $91.181 \mathrm{~km}$ yang di dalamnya terkandung sumber daya perikanan dan kelautan yang mempunyai potensi besar untuk dijadikan tumpuan pembangunan ekonomi berbasis sumber daya alam ( $w w w$.prospekperikananindonesiasma4.weebly.com)

Besarnya potensi ini terlihat dari tersedianya luas areal budidaya perikanan yang terus meningkat dalam enam tahun terakhir (2011-2016). Tahun 2011 luas area budidaya ikan mencapai 1,19 juta hektar dan ditahun 2016 telah mencapai 1,44 juta hektar. Menurut survey dalam 6 tahun terakhir kondisi perikanan dalam negeri semakin membaik, hal ini terlihat dari semakin meningkatnya produksi, baik produksi perikanan tangkap maupun budidaya dengan rata rata pertumbuhan mencapai $20 \%$ per tahun. Tahun 2011 perkembangan produksi perikanan budidaya mencapai 6,47 juta ton ditahun 2016 angkanya telah mencapai 19,75 juta ton, sedangkan produksi perikanan tangkap ditahun 2011 mencapai 5,71 juta ton dan tahun 2016 angkanya telah mencapai 7,97 juta ton. Hingga akhir 2016 nilai produksi perikanan Indonesia mencapai Rp. 139,2 triliun. (survey PT CDMI consulting,2017)

Dua tahun lalu 2014 dan 2015 industri pengolahan ikan di Asia Tenggara masih dikuasai oleh Thailand dan Filipina, sedangkan Indonesia sebagai pemilik lautan terluas dan garis pantai terpanjang menduduki posisi ketiga. Namun ditahun 2016 kondisinya sudah berubah, kekuatan industri perikanan di Asia Tenggara telah dikendalikan Indonesia. Selama ini ikan-ikan yang diolah oleh Thailand dan Filipina untuk kemudian mereka ekspor sebenarnya banyak yang berasal dari perairan Indonesia. Dengan kebijakan moratorium perizinan kapal eks asing, kini semakin sulit menangkap ikan diperairan Indonesia ditambah dengan kebijakan larangan bongkar muat ikan di tengah laut (transhipment) menambah terpuruk industri perikanan Thailand dan Filipina, sehingga akhirnya mereka mengajukan permohonan membuka pabrik pengolahan ikan di Indonesia.

Disamping Filiphina dan Thailand. China, Peru,USA dan negara kelautan lainnya merupakan pesaing Indonesia sebagai produsen perikanan dunia. Persaingan harga dan kualitas merupakan salah satu tantangan yang dihadapi oleh perusahaan pengolahan perikanan di Indonesia dari tingkat regional maupun global baik untuk bahan baku/ikan mentah atau produk dengan nilai tambah (Saut,2014). Dalam era persaingan global dibutuhkan taktik dan strategi perusahaan secara menyeluruh agar dapat bersaing dengan perusahaan lain. Perusahaan yang memiliki produk yang berkualitas kemungkinan akan berhasil memenangkan persaingan karena dapat memuaskan kebutuhan dan keinginan konsumen. Perhatian penuh terhadap kualitas akan memberikan dampak positif kepada bisnis melaui dua cara, yaitu dampak terhadap biaya produksi dan dampak terhadap pendapatan (Gaspersz,2005).

Dampak terhadap biaya produksi terjadi melalui proses pembuatan produk yang memiliki derajat konformansi yang tinggi terhadap standar-standar sehingga bebas dari tingkat kerusakan yang mungkin terjadi. Pengendalian kualitas dibutuhkan untuk mengurangi atau meminimalisir tingkat kerusakan yang mungkin terjadi dalam proses pembuatan atau pengolahan produk sehingga tidak 
menimbulkan tambahan biaya yaitu biaya pengawasan kualitas dan tingkat kerusakan produk yang dihasilkan sangat sedikit. Usaha pengendalian kualitas merupakan usaha preventif (penjagaan) perusahaan yang dilaksanakan sebelum kesalahan kualitas produk terjadi.

Pelabuhan Perikanan Samudera (PPS) Kendari sebagai pusat industri perikanan terpadu di Kawasan Timur Indonesia kini menghimpun sedikitnya 27 industri pengolahan ikan dan industri penunjang lainnya. Dari 27 perusahaan yang tergabung dalam kawasan PPS terpadu di Kecamatan Abeli itu, sebanyak 12 perusahaan industri pengolahan ikan dan 15 perusahaan industri penunjang. Dari 12 perusahaan industri pengolahan ikan salah satu diantaranya adalah PT. Abadi Makmur Ocean (AMO) bergerak pada usaha penampungan dan pengolahan. (http://www.antarasultra.com/,2016).

PT. AMO mampu memproduksi total 300 ton/bulan pada saat musim puncak penangkapan ikan, sementara pada saat musim penangkapan normal total produksi siap jual yang mampu dihasilkan oleh perusahaan sekitar 100 ton/bulan dan pada masa paceklik seringkali perusahaan tidak mendapatkan bahan baku sehingga tidak beroperasi. Jenis ikan yang menjadi bahan baku PT. AMO berasal dari jenis Cakalang, Beby Tuna, Layang dan Deho dengan beragam ukuran. Jenis-jenis ikan ini diperoleh dair para nelayan tangkap yang beroperasi disekitar laut pesisir Kondari-Wawoni'i serta dari luar wilayah hingga Laut Sulawesi, laut Banda, Laut Maluku, dan Laut Arafuru.

PT. AMO memiliki standar operasional kerja sesuai dengan ketentuan K3 dengan standar mutu hasil yang tinggi karena untuk di ekspor. Selanjutnya waktu kerja karyawan juga telah terjadwal bagi pekerja tetap dengan ada insentif untuk lembur dan tip perusahaan. PT. AMO mempekerjakan tenaga kerja tetap sebanyak 40 karyawan termasuk staf dan sekretaris dan lebih dari 50 orang tenaga kerja lepas yang hampir secara keseluruhan merupakan tenaga kerja lokal dengan dominasi tingkat pendidikan rendah (SMA) namun memiliki pengalaman dan keterampilan yang tinggi di bidang pengolahan ikan.

Kegiatan produksi yang dilakukan oleh PT. AMO diperuntukan untuk keperluan konsumsi domestik dan ekspor. PT AMO dalam aktivitas produksinya melakukan pengendalian terhadap kualitas ikan yang dimulai sejak penangkapan, penanganan ikan Beby tuna di atas kapal oleh nelayan, penanganan ikan Beby tuna di pelabuhan /dermaga (Penerimaan di TP,Pencucian I, Pemotongan sirip,Sortasi Mutu, Pencucian II, Penimbangan, Pengusapan, Pengepakan dan Pelabelan) dan hingga pengiriman ke konsumen akhir.

Sebelum ikan Beby tuna di ekspor terlebih dahulu dilakukan pemeriksaan dari Bau, Warna, Kekenyalan, dan Rasa di tempat pendaratan tuna, kemudian setelah di periksa ikan diproses di unit pengolahan ikan. Proses ikan Beby tuna dilakukan dibawah pengawasan oleh quality control dari awal ikan masuk dan siap diekspor, tetapi fenomena empiris menunjukan bahwa ada permasalahan yang biasa terjadi adalah adanya komplain dari pelanggan terkait mutu ikan Beby tuna segar yang dikirim. Daging ikan Beby tuna setelah di terima di negara tujuan ditemukan adanya perubahan seperti warna yang sudah tidak merah, rasa yang berubah, dan daging ikan yang sudah tidak elastis atau kenyal lagi.

Berdasarkan pada uraian di atas maka dapat diketahui bahwa masalah pengendalian terhadap kualitas produk yang dihasilkan oleh sebuah perusahaan merupakan suatu hal yang penting dan membutuhkan kajian yang lebih mendalam 
dalam bentuk penelitian tentang "Penerapan Statistical Quality Control (SQC) Pada Pengolahan Komoditi Ekspor Ikan Beby Tuna. Manajemen Pengendalian Mutu Produksi pengolahan komoditi ekspor ikan Beby tuna yang nantinya diharapkan dapat memberikan kontribusi untuk meningkatkan kualitas produksi ikan Beby tuna dan memperluas pangsa pasar.

Tujuan dalam penelitian ini adalah untuk mengetahui pelaksanaan pengendalian mutu pada pengolahan Ikan Beby tuna beku apakah sudah berada pada batas kendali dengan menganalisis sistem pengendalian mutu untuk meminimumkan kerusakan pengolahan Ikan Beby tuna beku dengan pendekatan statistical quality control (SQC) pada PT. Abadi Makmur Ocean (AMO).

\section{Metode Penelitian}

Data kuantitatif yang dikumpulkan pada penelitian ini adalah jumlah produksi pengolahan jual Ikan Beby tuna beku ukuran $10 \mathrm{~kg}$ keatas komoditi ekspor pada bulan Oktober-November 2017, gaji karyawan pengawasan mutu (quality control), biaya jaminan mutu dalam pengolahan Ikan Beby tuna beku. Data kualitatif yang dicari mengenai situasi di PT AMO seperti gambaran tentang perusahaan, jenis produk yang dihasilkan, struktur organisasi perusahaan, dan pelaksanaan pengendalian mutu dalam pengolahan Ikan Beby tuna beku .

Teknik pemilihan responden dilakukan secara purposive yaitu lima orang responden yang dipilih secara sengaja dengan pertimbangan bahwa responden merupakan seseorang yang dianggap mengerti serta memahami mengenai manajemen keuangan, proses pengendalian mutu ikan, proses produksi penanganan dan pengolahan ikan Beby tuna beku, serta mutu ikan di PT AMO, sehingga mampu memberikan informasi sesuai dengan tujuan penelitian. Dengan demikian, peneliti memilih tiga orang karyawan dari perusahaan yang terdiri atas satu orang karyawan bagian pengendalian keuangan dan akuntansi perusahaan, satu orang karyawan bagian pengawasan mutu (quality control), satu orang bagian proses produksi penanganan dan pengolahan Ikan Beby tuna beku, serta dua orang mitra di PT AMO terdiri atas nelayan dan pedagang pengumpul.

Analisis data yang digunakan dalam penelitian ini yaitu analisis kualitatif dan analisis kuantitatif. Analisis kualitatif dilakukan melalui pendekatan deskriptif untuk mengetahui pelaksanaan pengendalian mutu pada pengolahan Ikan Beby tuna beku. Analisis kuantitatif digunakan untuk menganalisis sistem pengendalian mutu untuk meminimumkan kerusakan pengolahan Ikan Beby tuna beku menggunakan pendekatan statistical quality control (SQC) yaitu peta kendali (control chart) untuk mengetahui batasan pengawasan mutu dengan menggunakan metode Diagram Kendali P (P-chart) yang diolah melalui Software QM for Windows versi 5.2 pada Module Statistic Quality Control.). Prawirosentono dalam La Hatani (2007), peta kendali (control chart) adalah untuk membatasi toleransi penyimpangan (variasi) yang masih dapat diterima, baik karena akibat kelemahan tenaga kerja, mesin, dan sebagainya. Dalam statistik untuk memperoleh tingkat kepercayaan $99 \%$, maka batas toleransi \pm 3 standar penyimpangan dihitung dari standar ukuran. 


\section{Hasil dan Pembahasan}

\subsection{Pelaksanaan Pengendalian Mutu Pengolahan Ikan Beby Tuna Beku}

Kegiatan praproduksi dimulai pada saat ikan beby tuna didaratkan di atas Pelabuhan PPS Kendari dengan pegawai melakukan penyeleksian terhadap kelompok ikan beby tuna yang didaratkan, kelompok ikan beby tuna dalam boks yang kualitasnya tidak layak langsung dipisahkan. Selanjutnya ikan diperoleh dimuat dengan mobil untuk dibawa ke perusahaan. Pemindahan ikan beby tuna dari tempat transit ke dilakukan secara cepat menggunakan mobil untuk mencegah terjadinya peningkatan suhu tubuh ikan. Setelah tiba di perusahaan gebang perusahaan maka masuklah pada tahap produksi, ikan ikan beby dijemput oleh karyawan untuk selanjutnya dicuci, peralatan yang akan digunakan disiram dengan menggunakan air dingin dan akohol untuk meminimalisir kontaminasi bakteri. selanjutnya di bawa ke tempat penimbangan untuk diketahui berat dan kategori dari ukurannya seperti yang telah diterapkan oleh perusahaan. Tahap berikutnya ikan ikan beby yang telah di timbang tersebut kemudian dikemas dan dimasukan kedalam freezer untuk dibekukan selama beberapa saat menunggu ikan ikan beby yang sedang diolah sebelumnya habis. Setelah itu, ikan ikan beby diambil kembali untuk diadakan pengolahan dan kemudian dipacking dengan menggunakan karung yang beratnya untuk masing-masing karung mencapai $40 \mathrm{Kg}$. Setelah ikan beby tuna dipaking, untuk menunggu jumlah produksi yang sesuai jumlah penjualan maka ikan beby tuna yang dihasilkan di gudangkan selama beberapa waktu. Apabila kapal pengambil ikan beby tuna telah ada maka ikan beby tuna yang sudah digudang ini dikeluarkan kemudian didistribusikan melalui kapal ke konsumen yang membutuhkannya baik domsetik maupun mancanegara.

Aspek produksi sangat ditentukan oleh kualitas ikan beby tuna yang ditangkap oleh nelayan. Olehnya itu, pengontrolan terhadap kualitas ikan beby tuna dimulai sejak penangkapan oleh nelayan hingga pengiriman ke pihak yang membutuhkan ikan beby tuna yang dihasilkan harus ketat, namun yang mengambil peran besar dalam menjaga kualitas adalah perlakuan pada saat penangkapan dan penyimpanan di kapal nelayan. Ikan beby tuna yang telah layu dan cacat tidak dapat diterima oleh perusahaan lagi karena tidak sesuai dengan standar kualitas ekspor dan apabila tetap dipaksakan maka akan memperburuk citra perusahaan dimata mitra perusahaan dan konsumennya. Dalam menjaga kualitas ikan tetap terjaga PT AMO juga melakukan uji laboratorium setiap 6 bulan sekali, jadi dalam setahun uji laboratorium dilakukan 2 kali. Uji laboratorium dilakukan di Makassar dengan biaya pengetesan sebesar Rp 1.150.000.

Pengamatan Kondisi Sanitasi Higiene dan Lingkungan pada PT Abadi Makmur Ocean (AMO) secara keseluruhan kondisinya sudah sesuai dengan standar pengendalian mutu dan keamanan hasil perikanan di sentra penyedia pangan sehat yang di terapkan oleh Badan Karantina Ikan, Pengendalian Mutu Dan Keamanan Hasil Perikanan Selaku Otoritas Kompeten.

\subsection{Sistem Pengendalian Mutu dengan Pendekatan Statistical Quality Control}

Proses produksi beby tuna segar dilakukan sesuai dengan jumlah yang dipesan oleh pelanggan. Hal ini dilakukan untuk mengurangi terjadinya penumpukan bahan baku dan penurunan mutu beby tuna yang dihasilkan karena bahan baku tuna yang diproduksi menjadi tidak segar. Pengukuran pengendalian 
mutu proses produksi beby tuna dilakukan pada rata-rata berat tuna segar gelondongan pada bulan Oktober 2017. Hasil pengukuran pengendalian mutu tersebut dapat dilihat pada table berikut:

Tabel Hasil Evaluasi Rata-Rata Beby Tuna Pada Bulan Oktober 2017 PT AMO

\begin{tabular}{|l|r|}
\hline Total Sample Size & 19446 \\
\hline Total Defects & 7870 \\
\hline Percentage defects & 0.40471 \\
\hline Std dev of p-bar & 0.01613 \\
\hline z value & 3 \\
\hline Upper Control Limit & 0.4531 \\
\hline Center Line & 0.40471 \\
\hline Lower Control Limit & 0.356321 \\
\hline Sumber : Pengolahan Data & \\
\hline
\end{tabular}

Berdasarkan table di atas, hasil pengolahan data menunjukan besarnya nilai garis sentral yaitu 0,40471 atau 40,47\%, nilai batas kendali atas (UCL) yaitu 0,4531 atau $45,31 \%$ yang berarti jika produk yang cacat/rusak mencapai atau berada di atas batas kendali atas (UCL) maka proses beby tuna yang dilakukan pada perusahaan dianggap tidak efektif. Sebaliknya produk cacat/rusak berada pada batas kendali bawah (LCL) menunjukan nilai sebesar 0,3563 atau 35,63\% berarti proses produksi beby tuna menunjukan cukup efektif. Mengacu dari hasil perhitungan di atas, maka tingkat cacat/kerusakan ikan beby tuna yang diproduksi PT AMO Kendari dengan menggunakan $p$-chart yang diolah melalui Software $Q M$ for Windows dapat diilustrasikan pada gambar berikut :

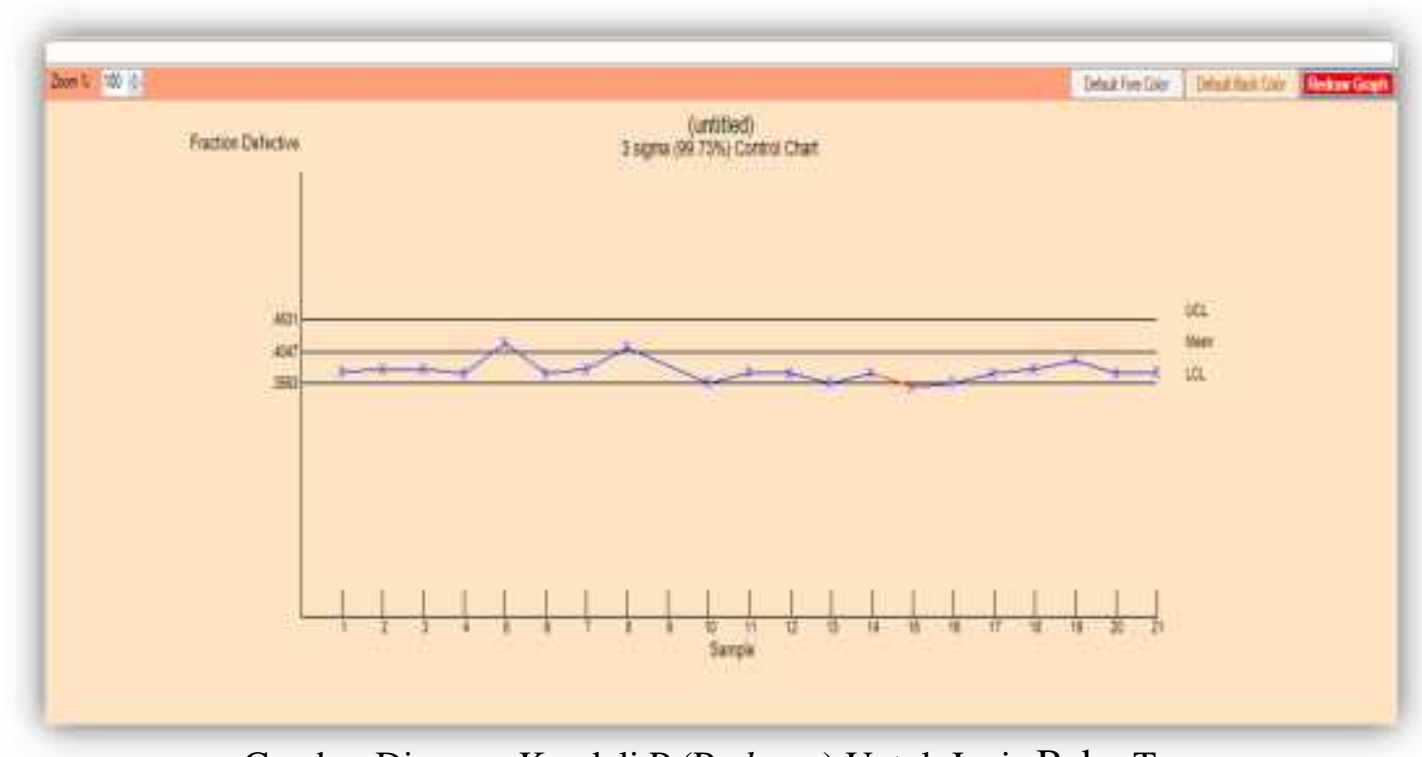

Gambar Diagram Kendali P (P-charts) Untuk Jenis Beby Tuna

Berdasarkan peta kendali pada gambar diatas secara umum dapat dilihat bahwa kondisi ikan beby tuna masih sesuai dengan kondisi bahan baku yang diharapkan perusahaan, hanya satu yang diluar batas kendali yaitu pada hari ke 15 . Hal seperti ini dihasilkan akibat variasi penyebab khusus (special cause effect) yang 
dapat bersumber dari faktor-faktor, seperti: manusia, peralatan, material, lingkungan, dan metode kerja (Gaspersz 2003).

\section{Kesimpulan}

Hasil analisis Statistical Quality Control (SQC) dengan metode diagram kendali P (P-charts) diketahui bahwa tingkat pencapaian standar yang diharapkan oleh perusahaan sudah tercapai. Hal ini terbukti dari hasil pemeriksaan sampel ikan beby tuna komoditas ekspor pada bulan oktober 2017 dengan 21 hari kerja, hanya satu hari yaitu hari ke 15 jumlah produk yang mengalami kerusakan karena berada diluar batas pengawasan kualitas atau terjadi penyimpangan kualitas. Pelaksanaan Pengendalian Mutu Pengolahan Ikan Beby Tuna pada PT. sudah memiliki standar operasional kerja sesuai dengan ketentuan K3 dengan standar mutu hasil yang tinggi karena untuk di ekspor. Pengamatan Kondisi Sanitasi Higiene dan Lingkungan pada PT Abadi Makmur Ocean (AMO) secara keseluruhan kondisinya sudah sesuai dengan standar pengendalian mutu dan keamanan hasil perikanan di sentra penyedia pangan sehat yang di terapkan oleh Badan Karantina Ikan, Pengendalian Mutu Dan Keamanan Hasil Perikanan Selaku Otoritas Kompeten.

\section{Daftar Pustaka}

Berita Antara Sultra, 2014. Perkuat Stabilitas Perikanan, KKP Jalankan SLIN, di Akses tanggal 20 Agustus 2017, http://www.antarasultra.com/,2016.

Gasperz, Vincent. 2005. Total Quality Management. Jakarta : PT. Gramedia Pustaka Utama.

Hatani, La. 2008. "Manajemen Pengendalian Mutu Produksi Roti Melalui Pendekatan Statistical Quality Control (SQC)." Diakses 20 Agustus 2017, dari www.google.com/Jurusan Manajemen FE Unhalu.

Hutagalung, Saut, 2014. Empat Tantangan Industri Perikanan Jelang MEA 2015, di akses tanggal 22 Agustus 2017, www.bisnis.com

Perikanan Indonesia, 2011. Prospek perikanan Indonesia, di akses tanggal 23 Agustus 2017, www.prospekperikananindonesiasma4.weebly.com 